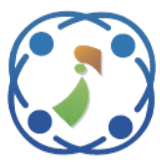

\title{
Load Active Power Transfer Enhancement Using UPQC-PV-BES System With Fuzzy Logic Controller
}

\author{
Amirullah Amirullah ${ }^{1 *}$ \\ Adiananda Adiananda ${ }^{1}$ \\ Ontoseno Penangsang ${ }^{2}$ \\ Adi Soeprijanto ${ }^{2}$ \\ ${ }^{1}$ Electrical Engineering Study Program, Faculty of Engineering, \\ Universitas Bhayangkara Surabaya, Surabaya 60231, Indonesia \\ ${ }^{2}$ Department of Electrical Engineering, Faculty of Intelligent Electrical and Informatics Technology, \\ Institut Teknologi Sepuluh Nopember, Surabaya 60111, Indonesia \\ *Corresponding author's Email: amirullah@ubhara.ac.id
}

\begin{abstract}
This paper presents enhancement of load active power transfer using Unified Power Quality ConditionerPhotovoltaic-Battery Energy Storage (UPQC-PV-BES) system. This system is connected to a three phase three wire (3P3W) system with a voltage of $380 \mathrm{~V}$ (line to line) and 50 hertz. The proposed model is also compared with UPQC and UPQC-PV respectively. The parameters investigated are load voltage, load current, load active power, and efficiency. BES functions to save excess energy generated by PV, distribute it to the load, avoid interruption voltage, and regulate the charging process and energy utilization. The fuzzy logic controller (FLC) is proposed and compared with proportional integral (PI) method to control DC voltage variable and input DC reference voltage, to produce a reference current source on hysteresis current controller on shunt active filter in 12 disturbance scenarios (scns). In Scenario (Scn) 1 to 5, the 3P3W system uses three combinations of UPQC with PI controller and FLC, still keeps load voltage and load current above $300 \mathrm{~V}$ and $8 \mathrm{~A}$. Whereas in Scn 6, only the UPQC-PV-BES with FLC is able to maintain load voltage and load current higher compared to UPQC and UPQC-PV combinations as $304.1 \mathrm{~V}$ and 8.421 A, respectively. In Scn 1 to 5, the 3P3W system uses three combinations of UPQC with PI controller and FLC, capable of producing load active power above $3600 \mathrm{~W}$. Whereas in Scn 6, only a combination of UPQC-PV-BES with PI controller and FLC is able to produce a load voltage of $3720 \mathrm{~W}$ and $3700 \mathrm{~W}$, respectively. In Scn 1 to 6, UPQC-PV-BES results in lower efficiency compared to using UPQC and UPQC-PV. However, in Scn 6, UPQC-PVBES with FLC is able to produce load voltage, load current, and load active power higher than UPQC-PV and UPQC. Thus, the UPQC-PV-BES model using FLC is able to compensate load voltage and load current, as well as to enhance load active power, especially for an interruption on source bus. This research is simulated using Matlab/Simulink.
\end{abstract}

Keywords: Load active power transfer, UPQC, PV, BES, FLC, Disturbance Scns.

\section{Introduction}

The degradation of fossil energy sources and increasing concerns about environmental impacts have caused renewable energy (RE) sources i.e. photovoltaic (PV) and wind to develop into alternative energy on power generation. Solar or PV generator is one of the most potential RE technologies because it only converts sunlight to generate electricity, where the resources are available in abundant and they are free and relatively clean. Indonesia has a huge energy potential from the sun because it is located in the equator. Almost all regions of Indonesia receive around 10 to 12 hours of sunshine per day, with an average radiation intensity of $4.5 \mathrm{kWh} / \mathrm{m}^{2}$ or equivalent to $112.000 \mathrm{GW}$.

Although, PV is able to generate power, this equipment also has disadvantage: it results in a number of voltage and current interferences, as well as harmonics due to the presence of several types of PV devices and power converters and increasing the 
number of non-linear loads connected to the source, causing a decrease in power quality (PQ). In order to overcome this problem and to improve PQ due to the presence of non-linear load and integration of PV into the grid, UPQC was proposed. This device has been a function to compensate for problems of voltage source quality i.e. sag, swell, unbalance, flicker, harmonics, and load current quality problems i.e. harmonics, imbalance, reactive current, and neutral current. UPQC was part of an active power filter consisting of shunt active filter and series active filter connected in parallel and serving as a superior controller to solve a number of PQ problems simultaneously [1].

UPQC series section was responsible for reducing a number of disturbances on source side i.e. sag/swell voltage, flicker, unbalanced voltage, and source voltage harmonics. This equipment serves to inject a certain amount of voltage to keep load voltage at desired level so that it returns to balance and distortion free. UPQC shunt section was responsible for overcoming current quality problems e.g. low power factor, load current harmonics, and unbalanced current. This device has a function of injecting current into AC system so that source current becomes a balanced sinusoidal and in phase with source voltage [2]. The design and dynamic performance of integrated PV with UPQC (PVUPQC) under variable radiation condition and voltage sag/swell, and load unbalance has been investigated [3]. The proposed system was able to combine both the benefits of distributed generators (DGs) and active power filters. The PV-UPQC combination was also able to reduce harmonics due to nonlinear loads and was able to keep total harmonics distortion (THD) of grid voltage, load voltage and grid current below the IEEE-519. The system was found to be stable under radiation variations, voltage sag/swell, and load unbalance conditions.

The dynamic performance of the proposed model based auto tuned PI controller for PV-UPQC systems has been analyzed [4]. Online model optimization methodology was implemented for PVUPQC to determine the best value of PI controller gain. The Vector-Proportional Integral (UV-PI) and Proportional Resonant-Response (PR-R) controllers in shunt and series converters significantly increase PV-UPQC performance by reducing convergence time, settling time, switching harmonics, complexity and dynamic response show that they became more effective. PV-UPQC performance using control algorithm based on Synchronous Reference Frame (SRF) with Phase Lock Loop (PLL) mechanism has been presented [5]. Unbalanced load voltage containing harmonics and pure unbalanced load voltage had been compensated and balanced so that the load voltage was kept constant by PV-UPQC.

UPQC was supplied by 64 PV panels using boost converters, PI controllers, maximum power point tracking (MPPT) with Pertub and Observer ( $\mathrm{P}$ and $\mathrm{O}$ ), and having a momentary reactive power theory (p-q theory) which has been proposed [6]. The system has succesfully to carried out reactive power compensation and reduced source current and load voltage harmonics. However, this study did not address mitigation of sag voltage reduction and other disturbances caused by PV penetration. PV supported by UPQC using Space Vector Pulse Width Modulation (SVPWM) compared to hysteresis control in a 3P3W distribution system has been proposed [7]. This model is used to improve PQ and to reduce the burden of three-phase AC network by supplying power obtained from PV array. The UPQC system was able to supply reactive power needed to increase power factor, reduce voltage and current distortion and help inject active power by PV into the load. A conceptual study of UPQC on three phase four wire $(3 \mathrm{P} 4 \mathrm{~W})$ system connected to linear and non-linear loads simultaneously has been carried out [8]. A sinusoidal current control strategy drives UPQC in such a way that the supply system draws a constant sinusoidal current under steady state conditions. In addition, the shunt converter also produced reactive power as required by load so that it could improve an input power factor and reduce THD of source current.

Artificial neural network (ANN) based on SRF theory as a control to compensate for PQ problems of $3 \mathrm{P} 3 \mathrm{~W}$ system through UPQC for various balanced/unbalanced/distorted conditions at load and source has been proposed [9]. The proposed model has successfully mitigated harmonics/reactive currents, unbalanced source and load, and unbalanced current/voltage. The weakness of neural network $(\mathrm{NN})$ requires time for learning (training) and testing process, so that it produces longer control responses when determining output variables. Investigation on PQ of enhancements including sag and source voltage harmonics on the grid using UPQC provided by PV array connected to DC links using PI compared to FLC has been conducted [10]. The simulation showed that FLC on UPQC and PV can improve THD voltage source better than PI.

The improvement of PQ using UPQC on microgrid supplied by PV and wind turbine has been implemented using PI and FLC. Both methods are able to improve PQ and to reduce distortion in output power [11]. Research on the use of BES in 
UPQC supplied by PV to improve PQ in $3 \mathrm{P} 3 \mathrm{~W}$ distribution systems using FLC validated PI controller on various disturbances in source and load side has been investigated [12]. The research showed that FLC on UPQC-BES supplied by PV was able to significantly reduce source current harmonics and load voltage harmonics in number of disturbances, especially in interruption voltage disturbance on source bus. The grid-connected UPQC combined with a PV generator was proposed by [13] using a converter topology and by [14] using dual UPQC applied to three phase four wire (3P4W) system. Both researches showed that the topology had the capacity to compensate for network disturbances, inject power generated by PV panels under different operating conditions, and was able to compensate THD voltage on load bus and THD current on source bus. Research on biogeographybased optimization with harmonic elimination techniques for modification of UPQC connected to smartgrid has been carried out [15]. Low-order harmonics are eliminated by choosing the right switching angle and at the same time high-order harmonics are suppressed by injecting the same harmonics magnitude but opposite the phase by other converters. Excitation from the UPQC converter modification is obtained from the PV panel. The firing angle of shunt-series converter is obtained in real-time from an angle already stored in the microcontroller memory.

The previous research on UPQC-PV which has been carried out aims to compensate for sag/swell voltage on source bus, to reduce THD caused by distorted supply and non-linear loads, as well as to mitigate unbalanced loads. However, this combination has several disadvantages. This system is unable to overcome voltage interruption in source bus if PV power connected to UPQC DC-link circuit is insufficient to meet load power and the duration of interruption (momentary) exceeds 3 seconds base on limit IEEE 1159-1995 Standard. This research proposes enhancement of load active power transfer using UPQC-PV-BES system that is connected to a $3 \mathrm{P} 3 \mathrm{~W}$ system with a voltage of $380 \mathrm{~V}$ (line to line) and 50 hertz. The effectiveness of the proposed model is validated with UPQC and UPQC-PV, respectively. BES functions to store excess energy generated by PV, distribute it to the load if necessary, prevent interruption voltage, and regulate the charging process and energy utilization. BES is also expected to be able to save surplus power generated by $\mathrm{PV}$ and be used as a backup power. The FLC is proposed and compared with PI method to control DC voltage variable and input DC
Table 1. Abbreviation

\begin{tabular}{|l|l|}
\hline \multicolumn{1}{|c|}{ Symbol } & \multicolumn{1}{c|}{ Description } \\
\hline UPQC & Unified Power Quality Conditioner \\
\hline PV & Photovoltaic \\
\hline BES & Battery Energy Storage \\
\hline RE & Renewable Energy \\
\hline DG & Distributed Generation \\
\hline FLC & Fuzzy Logic Controller \\
\hline PI & Proportional Integral \\
\hline NL & Non Linear Load \\
\hline MPPT & Maximum Power Point Tracking \\
\hline 3P3W & Three Phase Three Wire \\
\hline 3P4W & Three Phase Four Wire \\
\hline P and O & Perturb and Observe \\
\hline CBs & Circuit Breakers \\
\hline FIS & Fuzzy Inference System \\
\hline MFs & Membership Functions \\
\hline Scn & Scenario \\
\hline
\end{tabular}

reference voltage to produce a reference current source on hysteresis current controller on active shunt filter in 12 disturbance scns. The FLC is proposed and compared with PI, because it has a weakness in determining proportional and integral gain constants which remain using trial and error method. The parameters observed are voltage and current on source bus, voltage and current on load bus, source active power, series active power transfer, shunt active power, load active power, PV power, and BES power. The next step is to determine efficiency value of each UPQC combination to show which circuit has a higher performance in enhancing of load active power transfer and in maintaining of load voltage and load current.

This paper is presented as follow. Section 2 explains proposed method, UPQC-PV-BES system model, parameter simulation, PV circuit model, active series and shunt filter control, application of PI controller and FLC, as well as UPQC efficiency for proposed model. Section 3 shows results and discussion of load voltage, load current, source active power transfer, load active power transfer, series active power transfer, shunt active power transfer, PV power, BES power using FLC validated with PI controller. In this section, six disturbance scns are presented and the results are verified with Matlab/Simulink. Finally, this paper is concluded in Section 4. Table 1 shows the abbreviations used in this paper.

\section{Research method}




\subsection{Proposed method}

Fig. 1 shows the proposed model of PV connected to a 3P3W with $380 \mathrm{~V}$ (line-line) and 50 hertz, through a series of DC links UPQC and BES. The PV generator raises DC power at a constant temperature and solar radiation level $\left(1000 \mathrm{~W} / \mathrm{m}^{2}\right.$ and $25^{\circ} \mathrm{C}$ ) and is connected to BES through DC/DC boost converter circuit. The MPPT method with $\mathrm{P}$ and $\mathrm{O}$ algorithm helps $\mathrm{PV}$ to produce peak power, generate an output voltage, which then become an input voltage for DC/DC boost converter. The boost converter functions to adjust duty cycle value with PV output voltage as an input voltage to result an output voltage according to DC-link voltage. BES is connected to the DC-link which serves as energy storage and is expected to inject power to keep load voltage and load active power, especially for an interruption voltage from source bus.

Investigation of the proposed model is carried out on three UPQC combinations connected to 3P3W (on-grid) system via a DC link circuit. The three combinations are UPQC, UPQC-PV, and UPQC-PV-BES. Two single phase circuit breakers $(\mathrm{CBs})$ are used to connect and disconnect PV and BES to UPQC DC-link. Each combination of circuit in each condition consists of six disturbance scns i.e. NL (Non-Linear Load), Unbalance-NL (Unba-NL), Distorted-NL (Dis-NL), Sag-NL, Swell-NL, and
Interruption-NL (Inter-NL). FLC is used as DC voltage control on shunt active filter to fix PQ in each fault scn and the results are validated with PI control. Each scn in UPQC uses PI and FLC controller so that the total number of disturbances are 12. The measured parameters are voltage and current on the source bus, voltage and current on the load bus, source active power, series active power transfer, shunt active power, load active power, PV power, and BES power. The next step is to determine nominal of efficiency of each UPQC combination to show the circuit that has superior performance in maintaining load voltage, load current, and load active power under six disturbance scns. Fig. 2 shows active power transfer using UPQC-PV-BES. Simulation parameters for the proposed model is shown in appendix section.

\subsection{Modelling of photovoltaic}

The equivalent circuit of solar panel is shown in Fig. 3. It consists of several PV cells which have external connections in series, parallel, or seriesparallel [16].

The V-I characteristic is shown in Eq. (1):

$$
I=I_{P V}-I_{o}\left[\exp \left(\frac{V+R_{S} I}{a V_{t}}\right)-1\right]-\frac{V+R_{S} I}{R_{P}}
$$

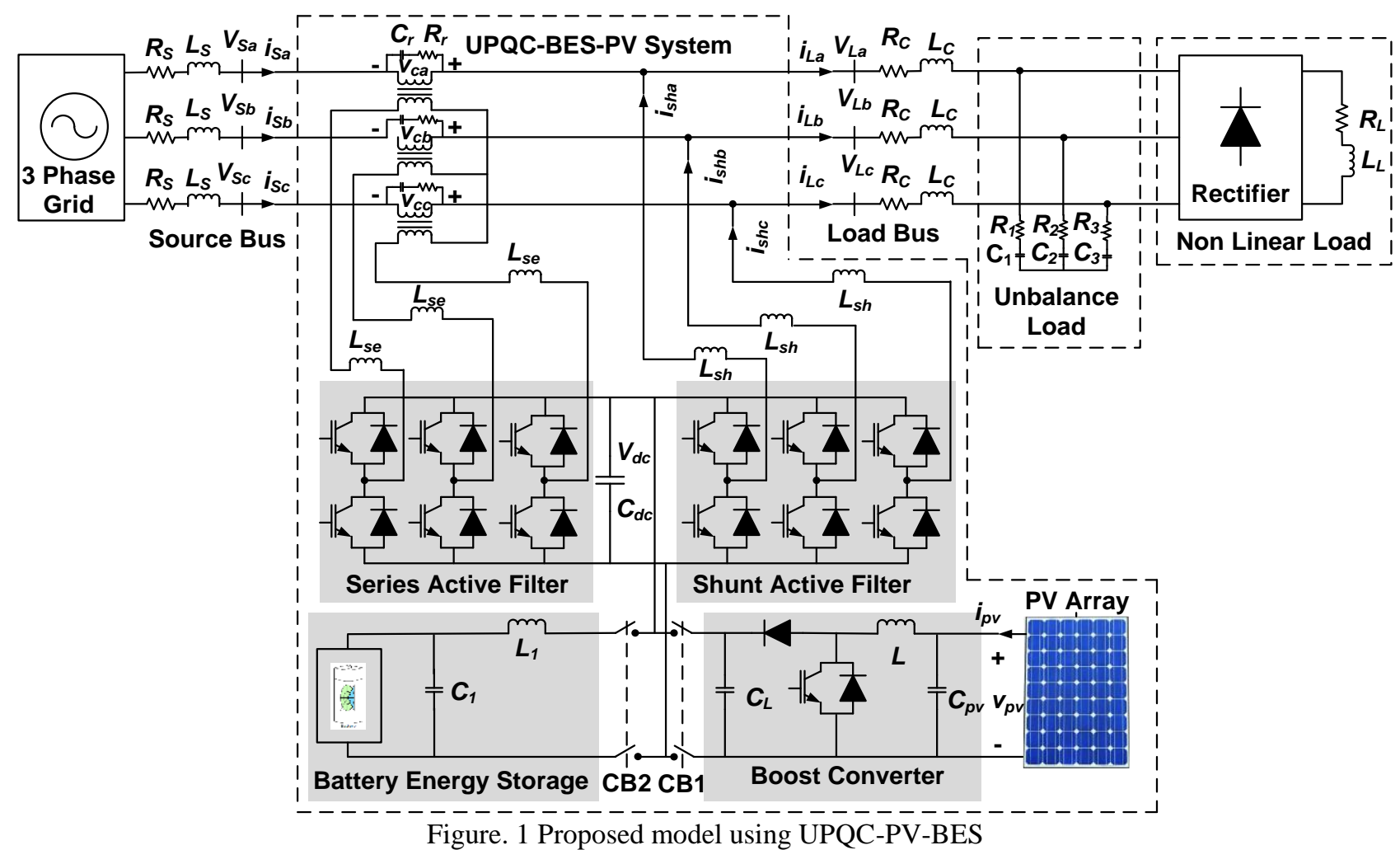




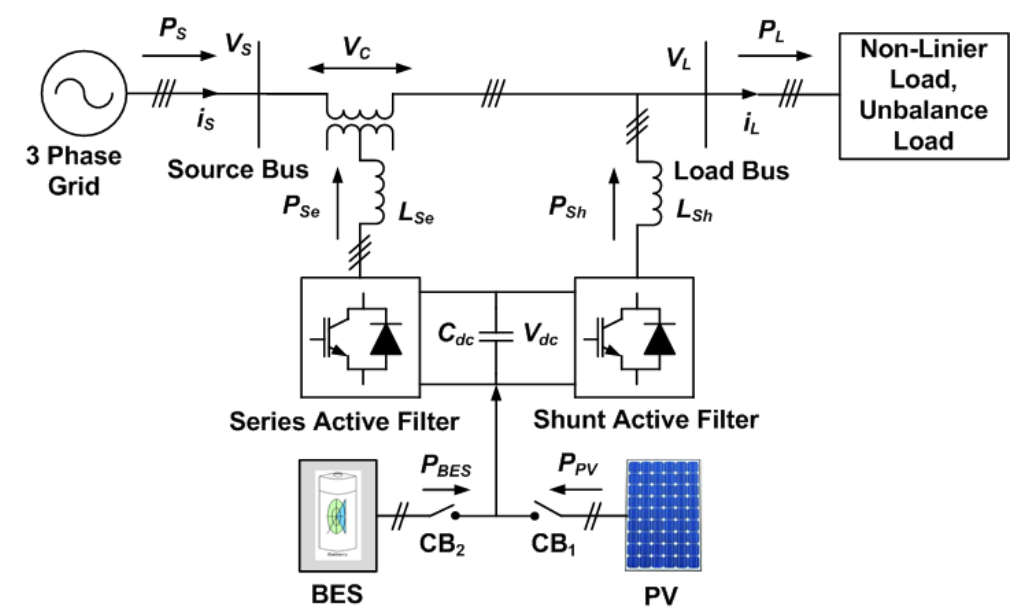

Figure. 2 Active power transfer using UPQC-PV-BES system

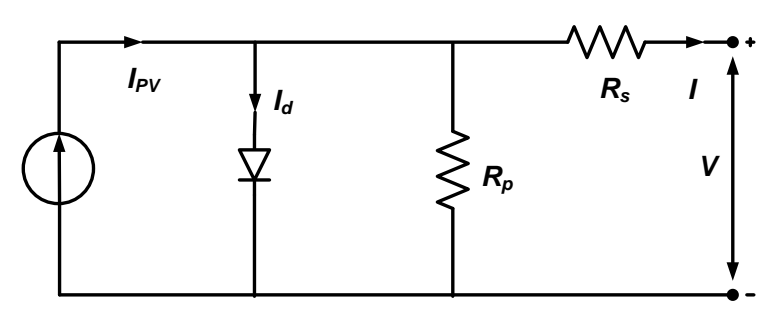

Figure. 3 Equivalent circuit of solar panel

Where $I_{P V}$ is $\mathrm{PV}$ current, $I_{o}$ is saturated re-serve current, 'a' is the ideal diode constant, $V t=$ $N_{S} K T q^{-1}$ is thermal voltage, $N_{S}$ is number of series cells, $q$ is electron charge, $K$ is Boltzmann constant, $T$ is temperature pn junction, $R_{S}$ and $R_{P}$ are series and parallel resistance of solar panels. $I_{P V}$ has a linear relationship with light intensity and also varies with temperature variations. $I_{o}$ is dependent value on the temperature variation. Eqs. (2) and (3) are the calculation of $I_{P V}$ and $I_{o}$ values:

$$
\begin{aligned}
& I_{P V}=\left(I_{P V, n}+K_{I} \Delta T\right) \frac{G}{G_{n}} \\
& I_{O}=\frac{I_{S C, n}+K_{I} \Delta T}{\exp \left(V_{O C, n}+K_{V} \Delta T\right) / a V_{t}-1}
\end{aligned}
$$

Where $I_{P V, n}, I_{S C, n}$, and $V_{O C, n}$ are the photovoltaic current, short circuit current, and open circuit voltage under standard conditions $\left(T_{n}=25^{\circ} \mathrm{C}\right.$ and $G_{n}=1000 \mathrm{~W} / \mathrm{m}^{2}$ ), respectively. The $K_{I}$ value is coefficient of short circuit current to temperature, $\Delta T=T-T_{n}$ is temperature deviation from standard temperature, $G$ is light intensity and $K_{V}$ is coefficient of open circuit voltage ratio to temperature. Open circuit voltage, short circuit current, and voltage-current related to maximum power are three important values of $\mathrm{I}-\mathrm{V}$ characteristics of solar panel. These points are changed by variation in atmospheric conditions. By using Eqs. (4) and (5) derived from PV model equation, short-circuit current and open circuit voltage can be calculated under different atmospheric conditions.

$$
\begin{aligned}
& I_{S C}=\left(I_{S C}+K_{I} \Delta T\right) \frac{G}{G_{n}} \\
& V_{O C}=\left(V_{O C}+K_{V} \Delta T\right)
\end{aligned}
$$

\subsection{Series active filter control}

The series active filter has the main function to protect sensitive load from a number of voltage disturbance at PCC bus. Fig. 4 shows algorithm of source voltage and load voltage control strategies in series active filter circuit. This control strategy generates the unit vector template from a distorted input source. Hereinafter, the template is expected to be an ideal sinusoidal signal with a unity power factor. Then, the distorted source voltage is measured and divided by peak amplitude of base input voltage $V_{m}$ in Eq. (6) [6].

$$
V_{m}=\sqrt{\frac{2}{3}\left(V_{s a}^{2}+V_{s b}^{2}+V_{s c}^{2}\right)}
$$

The 3 phase lock loop (PLL) is used to produce sinusoidal unit vector templates with phase lagging through the use of sine function. The load voltage of reference signal is determined by multiplying unit vector templates by the peak value of base input voltage amplitude $V_{m}$. Then, the load reference voltage $\left(V_{L a}^{*}, V_{L b}^{*}, V_{L c}^{*}\right)$ is compared with sensed load voltage $\left(V_{L a}, V_{L b}, V_{L c}\right)$ with a pulse width modulation (PWM) controller which is used to raise the desired trigger signal in series active filter. Fig. 4 shows control of series active filter. 


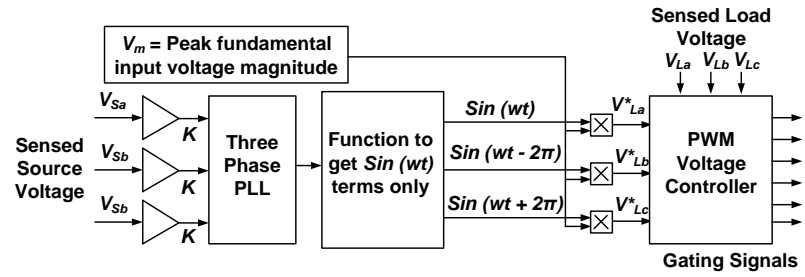

Figure. 4 Series active filter control

\subsection{Shunt active filter control}

The shunt active filter has the main function to mitigate PQ problems on the load side. The control methodology of shunt active filter is that the absorbed current from PCC bus is a balanced positive sequence current including an unbalanced sag voltage on PCC bus, an unbalanced, or a nonlinear load. In order to obtain satisfactory compensation caused by interference due to NL, many algorithms have been used in some literatures. This research uses the method of instantaneous reactive power theory or "p-q theory". The voltages and currents modeled in Cartesian coordinates can be transformed into Cartesian coordinates $\alpha \beta$ in Eqs. (7) and (8) [6].

$$
\begin{aligned}
& {\left[\begin{array}{l}
v_{\alpha} \\
v_{\beta}
\end{array}\right]=\left[\begin{array}{ccc}
1 & -1 / 2 & -1 / 2 \\
0 & \sqrt{3} / 2 & -\sqrt{3} / 2
\end{array}\right]\left[\begin{array}{l}
V_{a} \\
V_{b} \\
V_{c}
\end{array}\right]} \\
& {\left[\begin{array}{l}
i_{\alpha} \\
i_{\beta}
\end{array}\right]=\left[\begin{array}{ccc}
1 & -1 / 2 & -1 / 2 \\
0 & \sqrt{3} / 2 & -\sqrt{3} / 2
\end{array}\right]\left[\begin{array}{l}
i_{a} \\
i_{b} \\
i_{c}
\end{array}\right]}
\end{aligned}
$$

Eq. (9) shows calculation of real power $(p)$ and imaginary power $(q)$. The real and imaginary power are determined in instantaneously power and expressed in matrix form. Eq. (10) shows instantaneous section (mean and fluctuating) [17].

$$
\begin{aligned}
& {\left[\begin{array}{l}
p \\
q
\end{array}\right]=\left[\begin{array}{cc}
v_{\alpha} & v_{\beta} \\
-v_{\beta} & v_{\alpha}
\end{array}\right]\left[\begin{array}{l}
i_{\alpha} \\
i_{\beta}
\end{array}\right]} \\
& p=\bar{p}+\tilde{p} ; q=\bar{q}+\tilde{q}
\end{aligned}
$$

Where $\bar{p}=$ the average section of real power, $\tilde{p}$ $=$ the fluctuating section of real power, $\bar{q}=$ the average section of imaginary power, $\tilde{q}=$ the fluctuating section of imaginary power. The total imaginary power $(q)$ and fluctuating section of real power are selected as power and current references and are utilized through the use of Eq. (10) to compensate harmonics and reactive power [18].

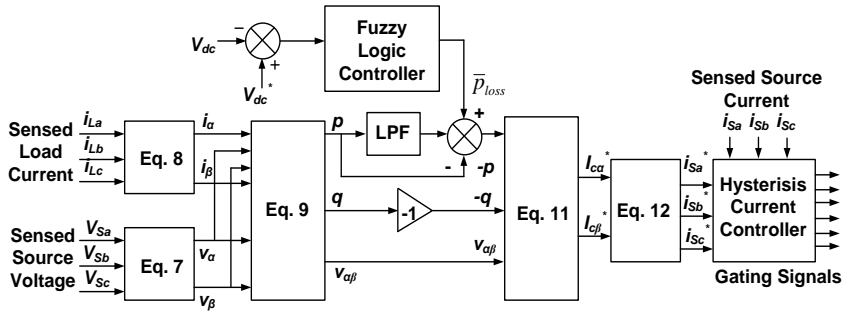

Figure. 5 Shunt active filter control

$$
\left[\begin{array}{c}
i_{c \alpha}^{*} \\
i_{c \beta}^{*}
\end{array}\right]=\frac{1}{v_{\alpha}^{2}+v_{\beta}^{2}}\left[\begin{array}{cc}
v_{\alpha} & v_{\beta} \\
v_{\beta} & -v_{\alpha}
\end{array}\right]\left[\begin{array}{c}
-\tilde{p}+\bar{p}_{\text {loss }} \\
-q
\end{array}\right]
$$

The $\bar{p}_{\text {loss }}$ signal is obtained from the voltage regulator and is used as average real power. It can also be expressed as instantaneous active power associated with resistive losses and switching losses from UPQC. The error is obtained by comparing the actual DC-link capacitor voltage with the reference value processed using a FLC, driven by a closed voltage control to minimize steady state errors from voltage through DC-link circuit to zero. The compensation current $\left(i_{c \alpha}^{*}, i_{c \beta}^{*}\right)$ is needed to meet load power demand as shown in Eq. (11). The current is expressed in coordinates $\alpha-\beta$. The compensation current is used to obtain source phase current by using Eq. (12) for compensation. The source phase current $\left(i_{s a}^{*}, i_{s a}^{*}, i_{s a}^{*}\right)$ is expressed in the abc axis obtained from the compensation current in $\alpha \beta$ coordinates and is presented in Eq. (12) [17]. Fig. 5 show shunt active filter control [18].

$$
\left[\begin{array}{l}
i_{s a}^{*} \\
i_{s b}^{*} \\
i_{s c}^{*}
\end{array}\right]=\sqrt{\frac{2}{3}}\left[\begin{array}{cc}
1 & 0 \\
-1 / 2 & \sqrt{3} / 2 \\
-1 / 2 & -\sqrt{3} / 2
\end{array}\right]\left[\begin{array}{l}
i_{c \alpha}^{*} \\
i_{c \beta}^{*}
\end{array}\right]
$$

The UPQC-PV-BES system must have a minimum DC-link $\left(V_{d c}\right)$ voltage in order to operate properly. The general DC-link voltage value depends on the instantaneous energy that can be generated by UPQC which is defined in Eq. (13) [19]:

$$
V_{d c}=\frac{2 \sqrt{2 V_{L L}}}{\sqrt{3} m}
$$

Where $m$ is the modulation index and $V_{L L}$ is the voltage of UPQC. Considering modulation index of 1 and the grid voltage between line-line $\left(\left(V_{L L}=\right.\right.$ $380 \mathrm{~V}), V_{d c}$ is obtained $620.54 \mathrm{~V}$ and chosen as 650 V. The input of shunt active filter shown in Fig. 6 is DC voltage $\left(V_{d c}\right)$ dan DC voltage reference $\left(V_{d c}^{*}\right)$ while the output is $P_{\text {loss }}$ by using the PI controller. Furthermore, $P_{\text {loss }}$ of the input variables produce source current reference $\left(i_{s a}^{*}, i_{s a}^{*}, i_{s a}^{*}\right)$. Then, the 
reference of source current output is compared with current source $\left(i_{s a}, i_{s b}, i_{s c}\right)$ by hysteresis current controller to generate a trigger signal in IGBT circuit of shunt active filter. In this paper, FLC as a DC voltage control algorithm on shunt active filter is proposed and compared with PI controller. FLC is able to reduce oscillations and to produce calculations with rapid convergence during interference. This method is also used to overcome the weaknesses of PI controller in determining proportional gain constants $\left(K_{P}\right)$ and integral gain constants $\left(K_{I}\right)$, which remain using the trial and error method.

\subsection{Fuzzy logic controller}

This research starts by determining $\bar{p}_{\text {loss }}$ as an input variable, to produce a reference source current on the hysteresis current control and to generate a trigger signal on the shunt active IGBT filter circuit from UPQC with PI control $\left(K_{P}=0.2\right.$ and and $\left(K_{I}=0.2\right)$. Using the same procedure, $\bar{p}_{\text {loss }}$ is also determined using FLC. This method has been widely used in industrial processes today because it has heuristic properties, is simpler and more effective, and has multi-rule-based variables in both linear and non-linear system. The FLC sections comprise fuzzification, decision making (rulebase, database, reason mechanism) and defuzzification in Fig. 6. The fuzzy rules algorithm collects a number of fuzzy control rules in a particular order. These rules are used to control the system so that it meets the desired performance requirements and they are designed from a number of intelligent control system knowledge. Fuzzy inference system (FIS) in FLC uses Mamdani Method with a max-min composition relationship. FIS consists of three parts i.e. rulebase, database, and reason-mechanism [20]. The FLC method is applied by determining input variables i.e. $\mathrm{V}_{\mathrm{dc}}$ error $\left(V_{d c-\text { error }}\right)$, delta $\mathrm{V}_{\mathrm{dc}}$ error $\left(\Delta V_{d c-e r r o r}\right)$, seven fuzzy linguistic pairs, fuzzy operating system blocks, $V_{d c-\text { error }}$ and $\Delta V_{d c-e r r o r}$ during seven fuzzy linguistic sets, fuzzy operating system blocks, $V_{d c-e r r o r}$ and $\Delta V_{d c-e r r o r}$ during fuzzification process, fuzzy rule base, as well as crips value to determine $\bar{p}_{\text {loss }}$ in defuzzification.

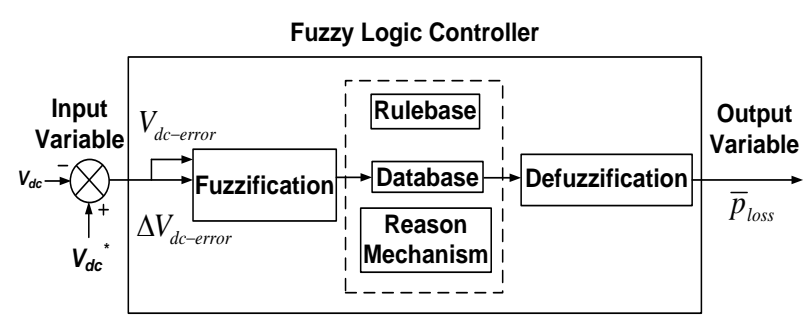

Figure. 6 Block diagram of FLC
The value of $\bar{p}_{\text {loss }}$ is one of the input variables to obtain the compensation current $\left(i_{c \alpha}^{*}, i_{c \beta}^{*}\right)$ in Eq. (16). During the fuzzification process, a number of input variables are calculated and converted into linguistic variables based on a subset called the membership function. The $V_{d c-e r r o r}$ and $\Delta V_{d c-e r r o r}$ are proposed as input variables with $\bar{p}_{\text {loss }}$ system output variables. In order to translate these variables, each input and output variable is designed using seven membership functions (MFs) i.e. Negative Big (NB), Negative Medium (NM), Negative Small (NS), Zero (Z), Positive Small (PS), Positive Medium (PM) and Positive Big (PB). The membership functions of input and output crips are presented with triangular and trapezoidal membership functions. The $V_{d c-e r r o r}$ ranges from 650 to $650, \Delta V_{\text {dc-error }}$ from -650 to 650 , and $\bar{p}_{\text {loss }}$ from -100 to 100 . The input and output MFs are shown in Figs. 7, 8, and 9.

After $V_{d c-e r r o r}$ and $\Delta V_{d c-e r r o r}$ are obtained, two input MFs are subsequently converted into linguistic variables and used as input function for FLC. The output MF is generated using inference block and basic rules of FLC as shown in Table 2 . Then, defuzzification block finally operates to change $\bar{p}_{\text {loss }}$ output generated from the linguistic variable to numeric again. The value of $\bar{p}_{\text {loss }}$ then

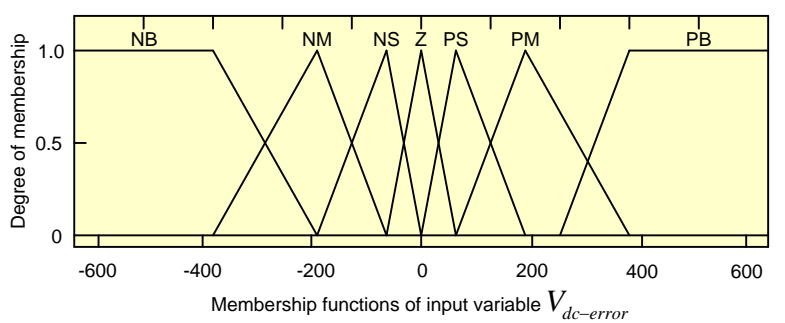

Figure. 7 Input MFs of $V_{d c-e r r o r}$

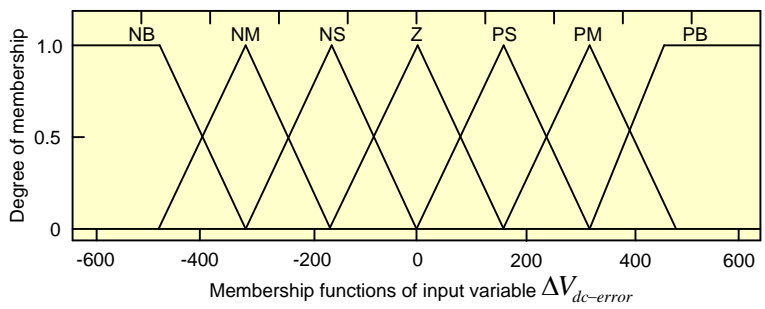

Figure. 8 Input MFs of $\Delta V_{d c-\text { error }}$

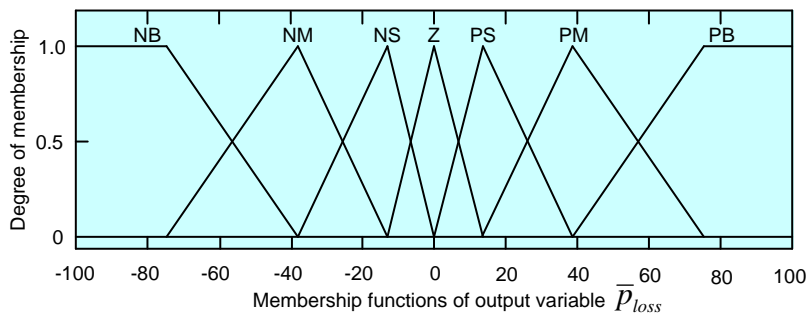

Figure. 9 Output MFs of $\bar{p}_{\text {loss }}$ 
Table 2. Fuzzy rule base

\begin{tabular}{|c|c|c|c|c|c|c|c|}
\hline$\frac{\mathbf{V}_{\text {dc-error }}}{\Delta \mathbf{V}_{\text {dc-error }}}$ & NB & NM & NS & $\mathbf{Z}$ & PS & PM & PB \\
\hline PB & Z & PS & PS & PM & PM & PB & PB \\
\hline PM & NS & $\mathrm{Z}$ & PS & PS & PM & $\mathrm{PM}$ & PB \\
\hline PS & NS & $\mathrm{NS}$ & $Z$ & PS & PS & PM & $\mathrm{PM}$ \\
\hline $\mathbf{Z}$ & $\mathrm{NM}$ & NS & NS & $\mathrm{Z}$ & PS & PS & $\mathrm{PM}$ \\
\hline NS & NM & NM & NS & NS & $\mathrm{Z}$ & PS & PS \\
\hline NM & $\mathrm{NB}$ & NM & NM & NS & NS & $\mathrm{Z}$ & PS \\
\hline NB & NB & NB & NM & NM & NS & NS & $\mathrm{Z}$ \\
\hline
\end{tabular}

becomes the input variable for current hysteresis control to produce a trigger signal in the IGBT circuit of UPQC shunt active filter to reduce source current harmonics and load voltage harmonics. Simultaneously, it also improves PQ of 3P3W system under six disturbance scns of three combination model i.e. UPQC, UPQC-PV, and UPQC-PV-BES, respectively.

\subsection{UPQC-PV-BES efficiency}

The 3-Phase 4-Leg Unified Series-Parallel Active Filter Systems using Ultra Capacitor Energy Storage (UCES) to mitigate sag and unbalance voltage has been investigated [21]. In this paper, it is found that the implementation of UCES is able to help system reduce source current compensation when sag voltage is on source bus to keep load voltage constant and balanced. During disturbance UCES generates extra power flow to load through a series active filter via dc-link and a series active filter to load. Although providing an advantage of sag voltage compensation, the use of UCES in this proposed system is also capable of generating losses and efficiency system. Using the same procedure, the authors propose Eq. (14) for efficiency of UPQC-PV-BES in the formula below.

$$
E_{f f}(\%)=\frac{P_{\text {Source }}+P_{\text {Series }}+P_{\text {Shunt }}+P_{P V}+P_{B E S}}{P_{\text {Load }}}
$$

\section{Results and discussion}

The proposed model is determined using three UPQC combinations connected to 3P3W system (on-grid) via a DC link circuit. The three combinations are UPQC, UPQC-PV, and UPQCPV-BES. Two single phase CBs are used to connect and disconnect PV and BES circuit to UPQC-DC link circuit. Each combination of sequences of each condition consists of six disturbance scns, i.e. NL, Unba-NL, Dis-NL, Sag-NL, Swell-NL, and InterNL. In Scn 1, the system is connected to non-linear loads with $\mathrm{R}$ and $\mathrm{L}$ values of $60 \mathrm{Ohms}$ and $0.15 \mathrm{mH}$, respectively. In Scn 2, the system is connected to non-linear loads for $0.3 \mathrm{~s}$ since $\mathrm{t}=0.2 \mathrm{~s}$ to $\mathrm{t}=0.5 \mathrm{~s}$ and also connected to three phase unbalanced load with values $R_{1}, R_{2}$ and $R_{3}$ of 6,12 , and $24 \mathrm{Ohm}$ respectively and $C_{1}, C_{2}$ and $C_{3}$ of $2.2 \mu \mathrm{F}$. In Scn 3, the system is connected to non-linear load and distorted voltage sources which results in $5^{\text {th }}$ and $7^{\text {th }}$ harmonics with individual harmonics distortion values of $5 \%$ and $2 \%$, respectively. In $\operatorname{Sen} 4$, the system is connected to a non-linear load and the source experiences a $50 \%$ sag voltage disturbance for $0.3 \mathrm{~s}$ between $\mathrm{t}=0.2 \mathrm{~s}$ to $\mathrm{t}=0.5 \mathrm{~s}$. In Scn 5, the system is connected to a non-linear load and the source experiences a $50 \%$ swell voltage disturbance for $0.3 \mathrm{~s}$ between $\mathrm{t}=0.2 \mathrm{~s}$ to $\mathrm{t}=0.5 \mathrm{~s}$. In $\mathrm{Scn} 6$, the system is connected to a non-linear load and the source experiences $100 \%$ an interruption voltage for $0.3 \mathrm{~s}$ between $\mathrm{t}=0.2 \mathrm{~s}$ to $\mathrm{t}=0.5 \mathrm{~s}$. Each combination uses an UPQC control with a FLC validated by PI so that there are $12 \mathrm{scns}$ in total.

Then, using Matlab/Simulink, each combination model is run according to the desired sen to obtain the curve of source voltage $\left(V_{S}\right)$, load voltage $\left(V_{L}\right)$, compensation voltage $\left(V_{C}\right)$, source current $\left(I_{S}\right)$, load current $\left(I_{L}\right)$, and DC-link voltage $\left(V_{d c}\right)$. Based on this curve, the average values of source voltage, load voltage, source current and load current are obtained based on the value of each phase voltage and current parameters previously obtained. The next process is determining the value of power transfer of source active power $\left(P_{S}\right)$, series active power $\left(P_{S e}\right)$,shunt active power $\left(P_{S h}\right)$, load active power $\left(P_{L}\right) \mathrm{PV}$ power $\left(P_{P V}\right)$, and BES power $\left(P_{B E S}\right)$. The measurement of nominal of voltage and current on source and load bus, UPQC power transfer, PV power, and BES are determined in one cycle starts at $\mathrm{t}=0.35 \mathrm{~s}$. The results of the average source voltage, source current, load voltage, and load current on the three proposed UPQCs are presented in Tables 3, 4, and 5 .

Table 3 shows that in $\operatorname{Scn} 1$ to 5 , the 3P3W system using UPQC with PI control is still able to maintain the average load voltage $\left(V_{L}\right)$ between 309.9 to 310.6 V. But in Scn 6, average load voltage drops to $169.1 \mathrm{~V}$. In the same system and scns 1 to 5 using FLC control, average load voltage rises slightly from 310.0 to $310.4 \mathrm{~V}$. But in Scn 6, the average load voltage drops to $160.4 \mathrm{~V}$. Table 3 also shows that in scns 1 to 5 , the $3 \mathrm{P} 3 \mathrm{~W}$ system using UPQC with PI control is still able to maintain the average load current $\left(I_{L}\right)$ between 8,585 to 8,634 A. But in Scn 6, the average load current drops to 4,578 A. On the same system and Scn 1 to 5 using FLC control, the average load current rises slightly 
from 8,587 to 8,623 A. But in Scn 6, the average load current drops slightly to 4,337 A.

Table 4 shows that in $\operatorname{Scn} 1$ to 5, the 3P3W system using UPQC-PV with PI control is still able to keep the average load voltage $\left(V_{L}\right)$ between 310.0 to $310.5 \mathrm{~V}$. However, in Scn 6, the average load voltage drops to $240.4 \mathrm{~V}$. In the system and with Scn 1 through 5 using FLC control, the average load voltage rises slightly from 310.1 to $310.5 \mathrm{~V}$. But in Scn 6, the average load voltage drops to $215.4 \mathrm{~V}$. Table 4 also shows that in Scn 1 to 5, the 3P3W system using UPQC with PI control is still able to maintain the average load current $\left(I_{L}\right)$ of 8,586 to 8,627 A. But in Scn 6, the average load current drops to $6,477 \mathrm{~A}$. In the same system and Scn 1 to 5 using FLC control, the average load current rises slightly from 8,578 to $8,635 \mathrm{~A}$. But in Scn 6 , the average load current drops significantly to 5,921 A.

Table 5 shows that in $\operatorname{Scn} 1$ to 5 , the $3 \mathrm{P} 3 \mathrm{~W}$ system using UPQC-PV-BES with PI control is still able to maintain the average load voltage $\left(V_{L}\right)$ between 307.2 to $308.2 \mathrm{~V}$. However, in Scn 6, the average load voltage drops to $286.7 \mathrm{~V}$. In the same system and Scn 1 to 6 using FLC control, the average load voltage rises slightly from 304.1 to 314.1 V. Table 5 also shows that in Scn 1 to 6, the 3P3W system using UPQC with PI control is still able to maintain the average load current $\left(I_{L}\right)$ of 8,031 to 8,746 A. In the same system and Scn 1 to 6 using FLC, the average load curren rises slightly from 8,421 to $8,718 \mathrm{~A}$.

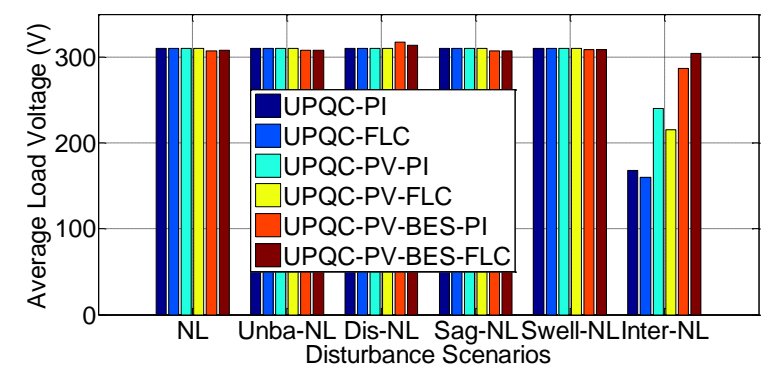

Figure. 10 Performance of load voltage using three UPQC combinations in six fault scns

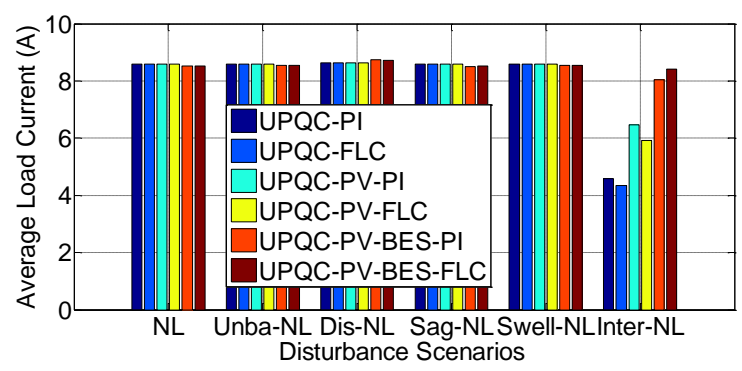

Figure. 11 Performance of load current using three UPQC combinations in six fault scns
Fig. 10 shows performance of load voltage and Fig. 11 shows performance of load current from the 3P3W system using three UPQC combinations in six disturbance scns with PI control and FLC.

Fig. 10 shows that in $\operatorname{Scn} 1$ to 5 , the 3P3W system using three combinations of UPQC with PI control and FLC is able to maintain load voltage $\left(V_{L}\right)$ above $300 \mathrm{~V}$. Whereas in Scn 6, only a combination of UPQC-PV-BES with FLC is able to generated load voltage $\left(V_{L}\right)$ is $304.1 \mathrm{~V}$. Fig. 11 shows that in $\operatorname{Scn} 1$ to 5 , the $3 \mathrm{P} 3 \mathrm{~W}$ system uses three combinations of UPQC with PI controller and FLC is able to maintain load current $\left(I_{L}\right)$ above $8 \mathrm{~A}$. Whereas in Scn 6, only the UPQC-PV-BES combination with PI control and FLC is capable of generating load current $\left(I_{L}\right)$ of $8.031 \mathrm{~A}$ and $8.421 \mathrm{~A}$, respectively. Therefore, in $\operatorname{Scn} 6$, the combination of UPQC-PV-BES with FLC provides better load voltage $\left(V_{L}\right)$ and load current $\left(I_{L}\right)$ performance than both the UPQC and UPQC-PV combination.

Fig. 12 shows the performance of UPQC combinations using FLC: (a) UPQC, (b) UPQC-PV, (c) (UPQC-PV-BES in Scn 4 (Sag-NL). Fig. 13 shows same performance of UPQC combinations using FLC: (a) UPQC, (b) UPQC-PV, (c) (UPQCPV-BES using FLC but in Scn 6 (Inter-NL). Fig. 12.a.i shows in Scn 4 of the UPQC combination at $t$ $=0.2 \mathrm{~s}$ to $\mathrm{t}=0.5 \mathrm{~s}$, the average source voltage $\left(V_{S}\right)$ drops by $50 \%$ from $310.1 \mathrm{~V}$ to $153.4 \mathrm{~V}$. During sag period, the average source current $\left(I_{S}\right)$ increases to 16.39 A (Fig. 12 (a.iv)) to compensate for reduction in load power and to maintain the average load voltage $\left(V_{L}\right)$ of 310.1 (Fig. 12 (a.ii)). The series active filter then supplies power to the load through the UPQC DC-link circuit and injects a compensation voltage $\left(V_{C}\right)$ of $156.7 \mathrm{~V}$ (Fig. 12 (a.iii)) through the injection transformer. At the same time, FLC of an active shunt filter works to keep the DC voltage $\left(V_{d c}\right)$, stable the average current source $\left(V_{d c}\right)$, increases approach to $16.39 \mathrm{~A}$ (Fig. 12 (a.iv)) to maintain the average current $\left(I_{L}\right)$ remain stable at $8.588 \mathrm{~A}$ (Fig. 12 (a.v)).

Fig. 12 (b.i) shows in Scn 4 of the UPQC-PV combination at $\mathrm{t}=0.2 \mathrm{~s}$ to $\mathrm{t}=0.5 \mathrm{~s}$, the average source voltage $\left(V_{S}\right)$ drops by $50 \%$ from $310.1 \mathrm{~V}$ to $153.8 \mathrm{~V}$. During sag period, the average source current increases slightly to 13.51 A (Fig. 12 (b.iv)) because PV generates power to the load through DC-link of a series active filter by injecting voltage compensation voltage $\left(V_{C}\right)$ of $153.8 \mathrm{~V}$ (Fig. 12 (b.iii)) through an injection transformer in series active filter so that the average load voltage $\left(\mathrm{V}_{\mathrm{L}}\right)$ remains stable at $310.1 \mathrm{~V}$ (Fig. 12 (b.ii)). At the 
Table 3. Voltage and current of 3P3W system using UPQC

\begin{tabular}{|c|c|c|c|c|c|c|c|c|c|c|c|c|c|c|c|c|}
\hline \multirow[t]{2}{*}{ Sen } & \multicolumn{4}{|c|}{$\begin{array}{c}\text { Source Voltage } V_{S} \\
\text { (Volt) }\end{array}$} & \multicolumn{4}{|c|}{$\begin{array}{c}\text { Load Voltage } V_{L} \\
\text { (Volt) }\end{array}$} & \multicolumn{4}{|c|}{$\begin{array}{c}\text { Source Current } I_{S} \\
\text { (Ampere) }\end{array}$} & \multicolumn{4}{|c|}{$\begin{array}{l}\text { Load Current } I_{L} \\
\text { (Ampere) }\end{array}$} \\
\hline & $\mathbf{A}$ & B & $\mathbf{C}$ & Avg & $\mathbf{A}$ & B & C & Avg & $\mathbf{A}$ & B & $\mathbf{C}$ & Avg & $\mathbf{A}$ & B & $\mathbf{C}$ & Avg \\
\hline \multicolumn{17}{|c|}{ PI Controller } \\
\hline \multirow[t]{2}{*}{1} & 309. & 309 & 309. & 39. & 10. & 310. & 310. & 310. & 8.74 & & 8.75 & 74 & .58 & & & 3.58 \\
\hline & 5 & .5 & 5 & 5 & 0 & 0 & 0 & 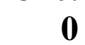 & 1 & & & 0 & 5 & & & 6 \\
\hline \multirow[t]{2}{*}{2} & 309. & 309 & 309. & 309. & 310. & 310. & 310. & 310. & 8.73 & 8.75 & 8.74 & 8.74 & 8.58 & 8.58 & 8.58 & 8.58 \\
\hline & 5 & .5 & 5 & 5 & 1 & 0 & 0 & $\mathbf{0}$ & 3 & 0 & 9 & 4 & 8 & 6 & & 6 \\
\hline \multirow[t]{2}{*}{3} & 309. & 309 & 309. & 309. & 309. & 312. & 310. & 310. & 8.85 & 8.77 & 8.80 & 8.80 & 8.53 & 8.76 & 8.5 & 8.63 \\
\hline & 5 & .5 & 5 & 5 & 1 & 6 & 1 & 6 & 5 & 2 & 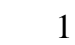 & 9 & 9 & 9 & & 4 \\
\hline \multirow[t]{2}{*}{4} & 153. & 153 & 153. & 153. & 310. & 310. & 310. & 310. & 16.4 & 16.3 & 16.4 & 16.4 & 8.58 & 8.58 & .58 & 8.58 \\
\hline & 4 & .4 & 4 & 4 & 1 & 1 & 1 & 1 & 2 & 9 & 2 & 1 & 8 & 8 & 8 & 8 \\
\hline \multirow[t]{2}{*}{5} & 464. & 464 & 464. & 464. & 309. & 309. & 309. & 309. & 8.38 & 8.38 & 8.38 & 8.38 & 8.58 & 8.58 & 8.58 & 8.58 \\
\hline & 6 & .6 & 6 & 6 & 9 & 9 & 9 & 9 & 0 & 8 & 0 & 3 & 5 & & & 5 \\
\hline \multirow[t]{2}{*}{6} & 1.01 & 0.9 & 1.01 & 1.00 & 173. & 161. & 169. & 168. & 9.47 & 9.35 & 9.02 & 9.28 & 4.86 & 4.46 & 4.40 & 4.57 \\
\hline & 7 & 82 & 4 & 4 & 5 & 2 & 5 & 1 & 9 & 3 & 7 & 6 & 6 & & & 8 \\
\hline \multicolumn{17}{|c|}{ Fuzzy Logic Controller } \\
\hline \multirow[t]{2}{*}{1} & 309. & 309 & 309. & 309. & 310. & 310. & 310. & 310. & 8.67 & 8.72 & 8.72 & 8.70 & 8.58 & 8.58 & 8.58 & 8.58 \\
\hline & 5 & .5 & 5 & 5 & 0 & 0 & 0 & 0 & 9 & 1 & 0 & 6 & 7 & 7 & & 6 \\
\hline \multirow[t]{2}{*}{2} & 309. & 309 & 309. & 309. & 310. & 310. & 310. & 310. & 8.71 & 8.68 & 8.70 & 8.70 & 8.58 & 8.58 & 8.58 & 8.58 \\
\hline & 5 & .5 & 5 & 5 & 0 & 0 & 0 & 0 & 3 & 7 & 0 & 0 & 6 & 7 & 8 & 7 \\
\hline \multirow[t]{2}{*}{3} & 309. & 309 & 309. & 309. & 308. & 311. & 310. & 310. & 8.81 & 8.70 & 8.70 & 8.74 & 8.53 & 8.73 & 8.60 & 8.62 \\
\hline & 5 & .5 & 5 & 5 & 9 & 6 & 5 & 4 & 6 & 3 & 3 & 1 & 3 & 4 & 3 & 3 \\
\hline \multirow[t]{2}{*}{4} & 153. & 153 & 153. & 153. & 310. & 310. & 310. & 310. & 16.3 & 16.3 & 16.4 & 16.3 & 8.58 & 8.58 & 8.58 & 8.58 \\
\hline & 4 & .4 & 4 & 4 & 1 & 1 & 1 & 1 & 9 & 8 & 1 & 9 & 8 & 8 & & 8 \\
\hline \multirow[t]{2}{*}{5} & 464. & 464 & 464. & 464. & 310. & 310. & 310. & 310. & 8.35 & 8.35 & 8.35 & 8.35 & 8.58 & 8.58 & 8.58 & 8.58 \\
\hline & 6 & .7 & 7 & 7 & 0 & 0 & 0 & 0 & 6 & 3 & 7 & 5 & 7 & 7 & 6 & 7 \\
\hline \multirow[t]{2}{*}{0} & 1.13 & 1.3 & 1.29 & 1.27 & 141. & 172. & 167. & 160. & 10.2 & 12.2 & 13.2 & 11.9 & 3.71 & 4.43 & 4.85 & 4.33 \\
\hline & & 77 & 9 & 0 & 4 & 2 & 4 & 4 & 2 & 3 & 7 & 1 & 8 & 8 & & 7 \\
\hline
\end{tabular}

Table 4. Voltage and current of 3P3W system using UPQC-PV

\begin{tabular}{|c|c|c|c|c|c|c|c|c|c|c|c|c|c|c|c|c|}
\hline \multirow[t]{2}{*}{ Sen } & \multicolumn{4}{|c|}{$\begin{array}{c}\text { Source Voltage } V_{S} \\
\text { (Volt) }\end{array}$} & \multicolumn{4}{|c|}{$\begin{array}{c}\text { Load Voltage } V_{L} \\
\text { (Volt) }\end{array}$} & \multicolumn{4}{|c|}{$\begin{array}{l}\text { Source Current } I_{S} \\
\text { (Ampere) }\end{array}$} & \multicolumn{4}{|c|}{$\begin{array}{l}\text { Load Current } I_{L} \\
\text { (Ampere) }\end{array}$} \\
\hline & $\mathbf{A}$ & B & C & Avg & $\mathbf{A}$ & B & C & Avg & $\mathbf{A}$ & B & $\mathbf{C}$ & Avg & $\mathbf{A}$ & B & $\mathrm{C}$ & Avg \\
\hline \multicolumn{17}{|c|}{ PI Controller } \\
\hline 1 & $\begin{array}{r}309 . \\
5\end{array}$ & $\begin{array}{r}309 . \\
5\end{array}$ & $\begin{array}{r}309 . \\
5\end{array}$ & $\begin{array}{r}309 . \\
5\end{array}$ & $\begin{array}{r}310 . \\
0\end{array}$ & $\begin{array}{r}310 . \\
0\end{array}$ & $\begin{array}{r}310 \\
.0\end{array}$ & $\begin{array}{r}310 . \\
0\end{array}$ & $\begin{array}{r}8.82 \\
8\end{array}$ & $\begin{array}{r}83 \\
8\end{array}$ & $\begin{array}{r}85 \\
8 \\
\end{array}$ & $\begin{array}{r}.84 \\
1\end{array}$ & $\begin{array}{r}3.58 \\
6\end{array}$ & & 5 & $\begin{array}{r}8.58 \\
6\end{array}$ \\
\hline 2 & $\begin{array}{r}309 . \\
5\end{array}$ & $\begin{array}{r}309 . \\
5\end{array}$ & $\begin{array}{r}309 . \\
5\end{array}$ & $\begin{array}{r}309 . \\
5\end{array}$ & $\begin{array}{r}310 . \\
0\end{array}$ & $\begin{array}{r}310 . \\
0\end{array}$ & $\begin{array}{r}310 \\
.0\end{array}$ & $\begin{array}{r}310 . \\
0\end{array}$ & $\begin{array}{r}8.75 \\
6\end{array}$ & $\begin{array}{r}8.77 \\
4\end{array}$ & $\begin{array}{r}8.74 \\
5\end{array}$ & $\begin{array}{r}8.75 \\
8\end{array}$ & $\begin{array}{r}8.58 \\
5\end{array}$ & 8.58 & 8.58 & $\begin{array}{r}8.58 \\
6\end{array}$ \\
\hline 3 & $\begin{array}{r}309 . \\
5\end{array}$ & $\begin{array}{r}309 . \\
5\end{array}$ & $\begin{array}{r}309 . \\
5\end{array}$ & $\begin{array}{r}309 . \\
5\end{array}$ & $\begin{array}{r}308 . \\
5\end{array}$ & $\begin{array}{r}312 . \\
1\end{array}$ & $\begin{array}{r}310 \\
.5\end{array}$ & $\begin{array}{r}310 . \\
5\end{array}$ & $\begin{array}{r}8.93 \\
6\end{array}$ & $\begin{array}{r}8.86 \\
3\end{array}$ & $\begin{array}{r}10.7 \\
3\end{array}$ & $\begin{array}{r}9.51 \\
0\end{array}$ & $\begin{array}{r}8.52 \\
2\end{array}$ & $\begin{array}{r}8.75 \\
7\end{array}$ & 8.60 & $\begin{array}{r}8.62 \\
7\end{array}$ \\
\hline 4 & $\begin{array}{r}153 . \\
8 \\
\end{array}$ & $\begin{array}{r}153 . \\
8 \\
\end{array}$ & $\begin{array}{r}153 . \\
8 \\
\end{array}$ & $\begin{array}{r}153 . \\
8 \\
\end{array}$ & $\begin{array}{r}310 . \\
1 \\
\end{array}$ & $\begin{array}{r}310 . \\
1 \\
\end{array}$ & $\begin{array}{r}310 \\
.1 \\
\end{array}$ & $\begin{array}{r}310 . \\
1 \\
\end{array}$ & $\begin{array}{r}13.3 \\
9 \\
\end{array}$ & $\begin{array}{r}13.3 \\
3 \\
\end{array}$ & $\begin{array}{r}13.4 \\
1 \\
\end{array}$ & $\begin{array}{r}13.3 \\
8 \\
\end{array}$ & $\begin{array}{r}8.58 \\
9 \\
\end{array}$ & $\begin{array}{r}8.58 \\
9 \\
\end{array}$ & $\begin{array}{r}8.58 \\
8 \\
\end{array}$ & $\begin{array}{r}8.58 \\
9\end{array}$ \\
\hline 5 & $\begin{array}{r}464 . \\
4\end{array}$ & $\begin{array}{r}464 . \\
4\end{array}$ & $\begin{array}{r}464 . \\
4\end{array}$ & $\begin{array}{r}464 . \\
4\end{array}$ & $\begin{array}{r}310 . \\
1\end{array}$ & $\begin{array}{r}310 . \\
1\end{array}$ & $\begin{array}{r}310 \\
.1\end{array}$ & $\begin{array}{r}310 . \\
1\end{array}$ & $\begin{array}{r}8.45 \\
7\end{array}$ & $\begin{array}{r}8.46 \\
8\end{array}$ & $\begin{array}{r}8.46 \\
0\end{array}$ & $\begin{array}{r}8.46 \\
2\end{array}$ & $\begin{array}{r}8.55 \\
8\end{array}$ & 8.59 & $\begin{array}{r}8.55 \\
8\end{array}$ & $\begin{array}{r}8.58 \\
7\end{array}$ \\
\hline 6 & $\begin{array}{r}1.19 \\
0 \\
\end{array}$ & $\begin{array}{r}1.31 \\
6\end{array}$ & $\begin{array}{r}1.23 \\
7\end{array}$ & $\begin{array}{r}1.24 \\
7\end{array}$ & $\begin{array}{r}229 . \\
2 \\
\end{array}$ & $\begin{array}{r}249 . \\
1\end{array}$ & $\begin{array}{r}242 \\
.8\end{array}$ & $\begin{array}{r}240 . \\
4\end{array}$ & $\begin{array}{r}11.3 \\
1\end{array}$ & $\begin{array}{r}11.8 \\
6 \\
\end{array}$ & $\begin{array}{r}11.9 \\
1\end{array}$ & $\begin{array}{r}11.6 \\
9\end{array}$ & $\begin{array}{r}6.44 \\
3 \\
\end{array}$ & $\begin{array}{r}6.69 \\
8 \\
\end{array}$ & $\begin{array}{r}6.28 \\
9\end{array}$ & $\begin{array}{r}6.47 \\
7 \\
\end{array}$ \\
\hline
\end{tabular}

same time, FLC on an active shunt filter works to keep DC voltage $\left(V_{d c}\right)$, stable and the average current source $\left(I_{S}\right)$, increases close to $13.51 \mathrm{~A}$ (Fig. 12 (b.iv)) to maintain the average load current $\left(I_{L}\right)$ remain stable at $8.578 \mathrm{~A}$ (Fig. 12 (b.v)).

Fig. 12 (c.i) also shows that the UPQC-PV-BES combination in $\operatorname{Scn} 4$ indicates almost the same performance on an average $V_{C}, V_{L}$, and $I_{L}$ values as presented in Fig. 12 (c.iii), (c.ii), and (c.v). The difference is that the average $I_{S}$ slightly decreases to 8,561 A (Fig. 12 (c.iv)) because part of reduction in load power has been compensated by power transfer from PV-BES combination to the load through DClink of series active filter and from a shunt active filter towards the load. The use of BES is able to prove that in addition to being able to store excess power from $\mathrm{PV}$, this combination is also able to 
Table 4. Voltage and current of 3P3W system using UPQC-PV (Continue)

\begin{tabular}{|r|r|r|r|r|r|r|r|r|r|r|r|r|r|r|r|r|}
\hline \multicolumn{10}{|c|}{} & \multicolumn{10}{|c|}{ Fuzzy Logic Controller } \\
\hline 1 & 309. & 309. & 309. & $\mathbf{3 0 9}$ & 310. & 310. & 310 & $\mathbf{3 1 0}$ & 8.76 & 8.73 & 8.81 & $\mathbf{8 . 7 7}$ & 8.57 & 8.58 & 8.58 & $\mathbf{8 . 5 8}$ \\
& 5 & 5 & 5 & $\mathbf{5}$ & 1 & 1 & .0 & $\mathbf{1}$ & 9 & 8 & 1 & $\mathbf{3}$ & 8 & 8 & 7 & $\mathbf{4}$ \\
\hline 2 & 309 & 309. & 309. & $\mathbf{3 0 9}$ & 310. & 310. & 310 & $\mathbf{3 1 0}$ & 8.67 & 8.68 & 8.67 & $\mathbf{8 . 6 7}$ & 8.58 & 8.58 & 8.58 & $\mathbf{8 . 5 8}$ \\
& 5 & 5 & 5 & $\mathbf{5}$ & 0 & 0 & .0 & $\mathbf{1}$ & 4 & 2 & 4 & $\mathbf{7}$ & 7 & 7 & 8 & $\mathbf{7}$ \\
\hline 3 & 309. & 309. & 309. & $\mathbf{3 0 9}$ & 309. & 312. & 309 & $\mathbf{3 1 0 .}$ & 8.93 & 8.82 & 8.91 & $\mathbf{8 . 8 9}$ & 8.55 & 8.76 & 8.58 & $\mathbf{8 . 6 3}$ \\
& 4 & 5 & 5 & $\mathbf{5}$ & 6 & 1 & .9 & $\mathbf{5}$ & 8 & 0 & 6 & $\mathbf{1}$ & 2 & 6 & 6 & $\mathbf{5}$ \\
\hline 4 & 153 & 153. & 153. & $\mathbf{1 5 3}$ & 310. & 310. & 310 & $\mathbf{3 1 0 .}$ & 13.5 & 13.4 & 13.5 & $\mathbf{1 3 . 5}$ & 8.55 & 8.58 & 8.58 & $\mathbf{8 . 5 7}$ \\
& 8 & 8 & 8 & $\mathbf{8}$ & 1 & 0 & .1 & $\mathbf{1}$ & 2 & 6 & 6 & $\mathbf{1}$ & 8 & 7 & 9 & $\mathbf{8}$ \\
\hline 5 & 464. & 464. & 464. & $\mathbf{4 6 4}$ & 310. & 310. & 310 & $\mathbf{3 1 0 .}$ & 8.35 & 8.37 & 8.36 & $\mathbf{8 . 3 6}$ & 8.59 & 8.58 & 8.58 & $\mathbf{8 . 5 8}$ \\
& 4 & 7 & 7 & $\mathbf{7}$ & 1 & 1 & .1 & $\mathbf{1}$ & 3 & 1 & 5 & $\mathbf{3}$ & 1 & 8 & 7 & $\mathbf{9}$ \\
\hline 6 & 1.25 & 1.28 & 1.53 & $\mathbf{1 . 3 5}$ & 209. & 193. & 242 & $\mathbf{2 1 5}$ & 13.2 & 11.4 & 14.0 & $\mathbf{1 2 . 9}$ & 6.45 & 5.00 & 6.29 & $\mathbf{5 . 9 2}$ \\
& 9 & 5 & 0 & $\mathbf{8}$ & 9 & 7 & .7 & $\mathbf{4}$ & 8 & 9 & 7 & $\mathbf{5}$ & 9 & 3 & 9 & $\mathbf{1}$ \\
\hline
\end{tabular}

Table 5. Voltage and current of 3P3W system using UPQC-PV-BES

\begin{tabular}{|c|c|c|c|c|c|c|c|c|c|c|c|c|c|c|c|c|}
\hline \multirow[t]{2}{*}{ Sen } & \multicolumn{4}{|c|}{$\begin{array}{c}\text { Source Voltage } V_{S} \\
\text { (Volt) }\end{array}$} & \multicolumn{4}{|c|}{$\begin{array}{c}\text { Load Voltage } V_{L} \\
\text { (Volt) }\end{array}$} & \multicolumn{4}{|c|}{$\begin{array}{l}\text { Source Current } I_{S} \\
\text { (Ampere) }\end{array}$} & \multicolumn{4}{|c|}{$\begin{array}{c}\text { Load Current } I_{L} \\
\text { (Ampere) }\end{array}$} \\
\hline & A & B & $\mathbf{C}$ & Avg & $\mathbf{A}$ & B & $\mathbf{C}$ & Avg & $\mathbf{A}$ & B & $\mathrm{C}$ & Avg & $\mathbf{A}$ & B & $\mathrm{C}$ & Avg \\
\hline \multicolumn{17}{|c|}{ PI Controller } \\
\hline 1 & $\begin{array}{r}309 . \\
6\end{array}$ & $\begin{array}{r}309 . \\
6\end{array}$ & $\begin{array}{r}309 . \\
6\end{array}$ & $\begin{array}{r}309 . \\
6\end{array}$ & $\begin{array}{r}307 . \\
6\end{array}$ & $\begin{array}{r}307 . \\
8\end{array}$ & $\begin{array}{r}307 . \\
7\end{array}$ & $\begin{array}{r}307 . \\
7\end{array}$ & $\begin{array}{r}7.76 \\
6\end{array}$ & $\begin{array}{r}79 \\
3\end{array}$ & $\begin{array}{r}75 \\
9\end{array}$ & $\begin{array}{r}7.77 \\
3\end{array}$ & $\begin{array}{r}3.52 \\
8\end{array}$ & $\begin{array}{r}52 \\
9\end{array}$ & $\begin{array}{r}53 \\
3\end{array}$ & $\begin{array}{r}8.53 \\
0\end{array}$ \\
\hline \multirow[t]{2}{*}{2} & 309. & 309. & 309. & 309. & 307. & 307. & 307. & 307. & 7.78 & 7.80 & 7.77 & 7.78 & 8.53 & 8.53 & 8.53 & 8.53 \\
\hline & 6 & 6 & 6 & 6 & 8 & 9 & 9 & 9 & 7 & 1 & 9 & 9 & 1 & 3 & & 4 \\
\hline \multirow[t]{2}{*}{3} & 309. & 309. & 309. & 309. & 313, & 314. & 317. & 317. & 7.89 & 7.91 & 7.86 & 7.89 & 8.74 & 70 & 8.78 & 8.74 \\
\hline & 6 & 6 & 6 & 6 & 8 & 3 & 4 & 4 & 7 & 9 & 7 & 5 & 8 & 4 & & 6 \\
\hline \multirow[t]{2}{*}{4} & 154. & 154. & 154. & 154. & 307. & 307. & 307. & 307. & 7.23 & 7.27 & 7.22 & 7.24 & 8.50 & 8.51 & 8.51 & 8.51 \\
\hline & 5 & 5 & 5 & 5 & 1 & 3 & 3 & 2 & 5 & 6 & 6 & 6 & 9 & 4 & & 1 \\
\hline \multirow[t]{2}{*}{5} & 64. & 64. & 464. & 464. & 308. & 308. & 308. & 308. & 7.97 & 7.98 & 7.96 & 7.97 & 8.55 & 8.55 & 8.55 & 8.55 \\
\hline & 7 & 7 & 7 & 7 & 6 & 7 & 6 & 6 & 9 & 0 & 4 & 5 & 0 & 3 & & 3 \\
\hline \multirow[t]{2}{*}{6} & 0.53 & 1.38 & 0.85 & 0.92 & 310. & 259. & 290. & 286. & 7.39 & 12.6 & 6.04 & 8.70 & 8.70 & 7.74 & 7.63 & 8.03 \\
\hline & 59 & 5 & 01 & 38 & 2 & 8 & 2 & 7 & 2 & 7 & 5 & 3 & 7 & & & 1 \\
\hline \multicolumn{17}{|c|}{ Fuzzy Logic Controller } \\
\hline \multirow[t]{2}{*}{1} & 99. & 99. & 309. & 09. & 07. & 307. & 307. & 307. & 8.42 & 8.42 & 8.41 & 8.42 & .52 & 53 & .53 & 8.53 \\
\hline & 5 & 5 & 5 & 5 & 7 & 9 & 7 & 8 & 0 & $\epsilon$ & 6 & 1 & 7 & 2 & & $\mathbf{0}$ \\
\hline \multirow[t]{2}{*}{2} & 309. & 309. & 309. & 309. & 307. & 308. & 307. & 307. & 8.40 & 8.40 & 8.40 & 8.40 & 8.53 & 8.53 & 8.53 & 8.53 \\
\hline & 5 & 5 & 5 & 5 & 9 & 0 & 9 & 9 & 2 & 3 & 1 & 2 & 5 & 9 & 6 & 7 \\
\hline \multirow[t]{2}{*}{3} & 309. & 309. & 309. & 309. & 313. & 312. & 315. & 314. & 8.51 & 8.56 & 8.49 & 8.52 & 8.74 & 8.67 & 8.73 & 8.71 \\
\hline & 6 & 5 & 5 & 5 & 4 & 9 & 9 & 1 & 6 & & 6 & 6 & 1 & 7 & & 8 \\
\hline \multirow[t]{2}{*}{4} & 154. & 154. & 154. & 154. & 307. & 307. & 307. & 307. & 8.56 & 8.56 & 8.56 & 8.56 & 8.51 & 8.51 & 8.51 & 8.51 \\
\hline & 4 & 4 & 4 & 4 & 3 & 3 & 2 & 3 & 3 & 0 & 1 & 1 & 4 & 7 & 2 & 5 \\
\hline \multirow[t]{2}{*}{5} & 464. & 464. & 464. & 464. & 308. & 308. & 308. & 308. & 8.39 & 8.38 & 8.38 & 8.39 & 8.55 & 8.55 & 8.55 & 8.55 \\
\hline & 6 & 6 & 6 & 6 & 6 & 8 & 6 & 7 & 6 & 9 & 9 & 2 & 2 & 6 & 4 & \\
\hline & 0.44 & 0.39 & 0.38 & 0.40 & 314. & 293. & 304. & 304. & 4.02 & 3.77 & 3.60 & 3.80 & 8.87 & 8.19 & 8.19 & 8.42 \\
\hline & 67 & 18 & 01 & 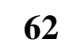 & 0 & 4 & 9 & 1 & 4 & 8 & 8 & 4 & 4 & 5 & 3 & 1 \\
\hline
\end{tabular}

inject current into the load through the DC-link (Fig. 12 (c.vi)) to produce the average $\mathrm{I}_{\mathrm{L}}$ remaining stable at $8.515 \mathrm{~A}$ (Fig. 12 (c.v)).

Fig. 13 shows the performance of UPQC combinations using FLC in Scn 6 (Inter-NL). Fig. 13 (a.i) shows that in Sen 6 of UPQC at $\mathrm{t}=0.2 \mathrm{~s}$ to $\mathrm{t}$ $=0.5 \mathrm{sec}$, the average $V_{S}$ drops by $100 \%$ to $1,270 \mathrm{~V}$. Under this condition, the capacitor in UPQC DClink is unable to produce maximum power and inject average $\mathrm{V}_{\mathrm{C}}$ (Fig. 13 (a.iii)) through an injection transformer in series active filter. So at $\mathrm{t}=0.2 \mathrm{~s}$ to $\mathrm{t}$ $=0.5$, the average $V_{L}$ in Fig. 13 (a.ii) decreases to
160.4 V. During interruption period, implementation of the FLC to shunt active filter is unable to maintain $V_{d c}$ (Fig. 13 (a.vi)) and the average $V_{C}$ constantly, which causes the average $I_{L}$ to also decrease to 4.337 A (Fig. 13 (a.v)).

Fig. 13 (b.i) shows that in Scn 6 of UPQC-PV combination at $\mathrm{t}=0.2 \mathrm{~s}$ to $\mathrm{t}=0.5 \mathrm{~s}$, the average $V_{S}$ drops by $100 \%$ to $1,358 \mathrm{~V}$. Under this condition, UPQC-PV is unable to generate maximum power to UPQC DC link and inject and average $V_{C}$ in Fig. 13 (a.iii) through an injection transformer in series active filter so at $\mathrm{t}=0.2 \mathrm{~s}$ to $\mathrm{t}=0.5 \mathrm{~s}$, the average $V_{L}$ 
in Fig. 13 (b.ii) decreases to 215.4 V. During interruption, application of FLC to shunt active filter is unable to maintain $V_{d c}$ (Fig.13 (b.vi)) and the average $V_{C}$ to remain constant, so an average $I_{L}$ is also decrease to 5,921 A (Fig. 13 (b.v)).

Fig. 13 (c.i) shows that the average $V_{S}$ also drops $100 \%$ to $0.4062 \mathrm{~V}$ in the UPQC-PV-BES combination at $\mathrm{t}=0.2 \mathrm{~s}$ to $\mathrm{t}=0.5 \mathrm{~s}$. During interruption period, the UPQC-PV-BES is able to generate power to UPQC DC-link and to inject the
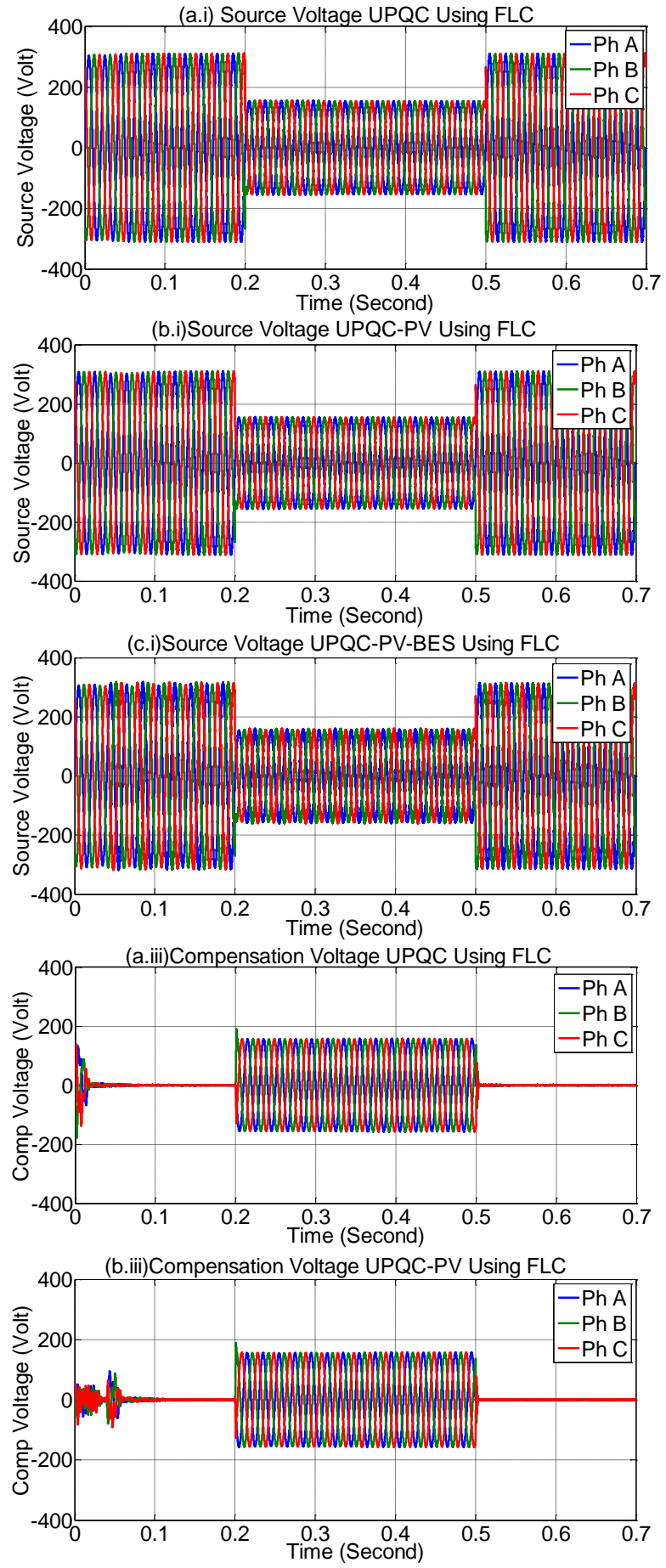

average $V_{C}$ (Fig.13 (c.iii)) through injection transformer in series active filter so that the average $V_{L}$ remains stable at $304.1 \mathrm{~V}$ (Fig. 13 (c.ii)). Even though the average $I_{S}$ drop to $3.804 \mathrm{~A}$ during interruption period, the UPQC-PV-BES combination is able to generate power, store excess energy from PV, and allow current to load through shunt active filter so that $I_{L}$ remains constant at 8,421 A (Fig. 13 (c.v)).
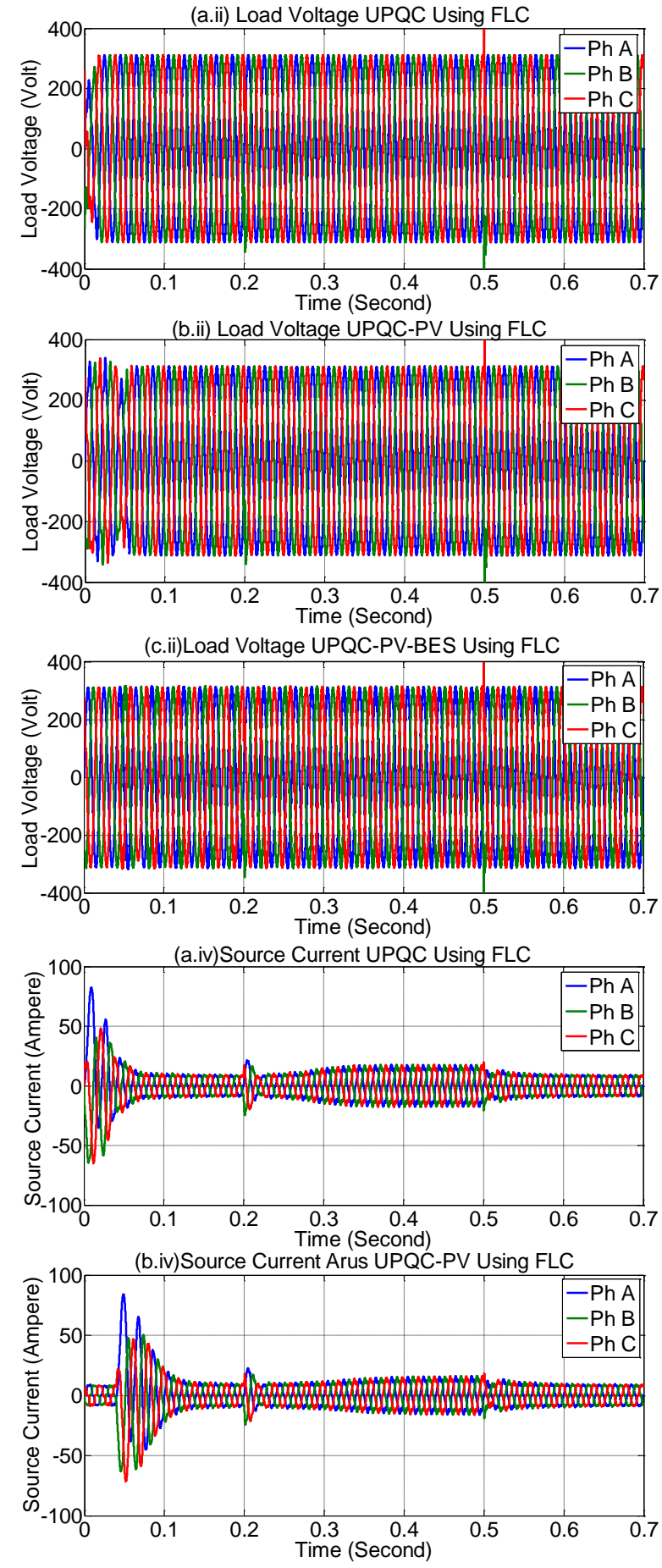
Received: January 2, 2020. Revised: February 13, 2020.
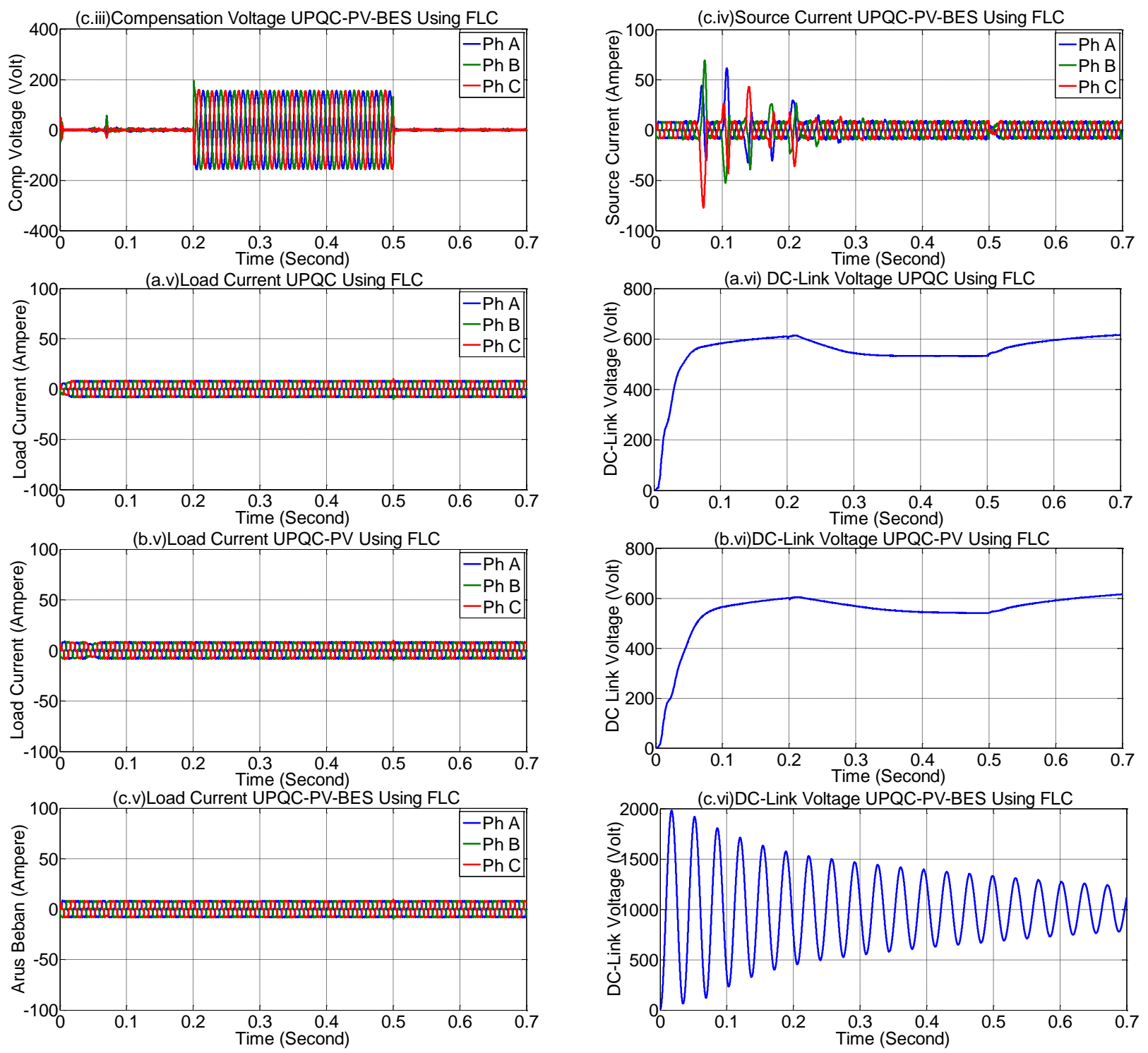

Figure. 12 Performance of UPQC combinations using FLC in Scn 4: (a) UPQC, (b) UPQC-PV, and (c) UPQC-PV-BES
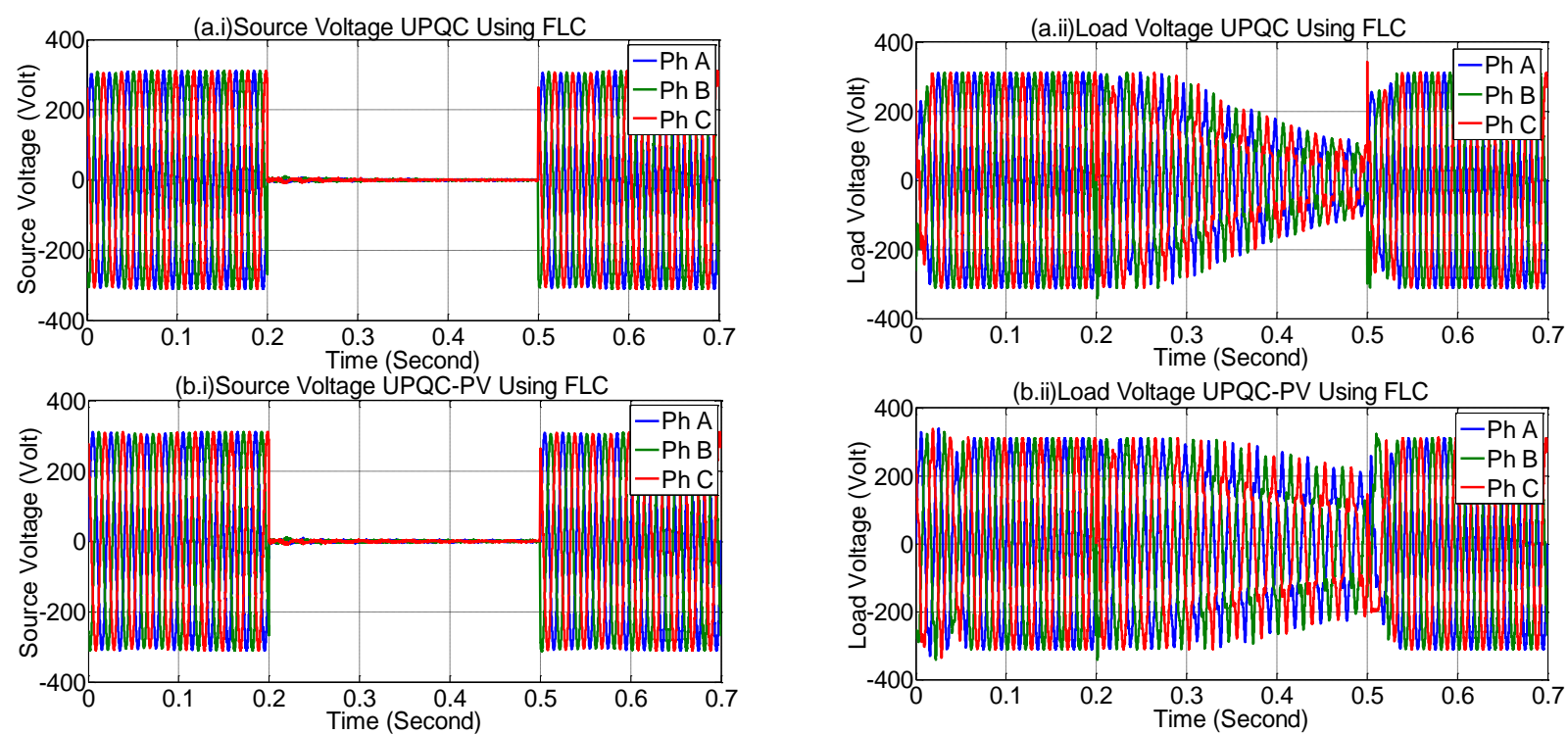
Received: January 2, 2020. Revised: February 13, 2020.
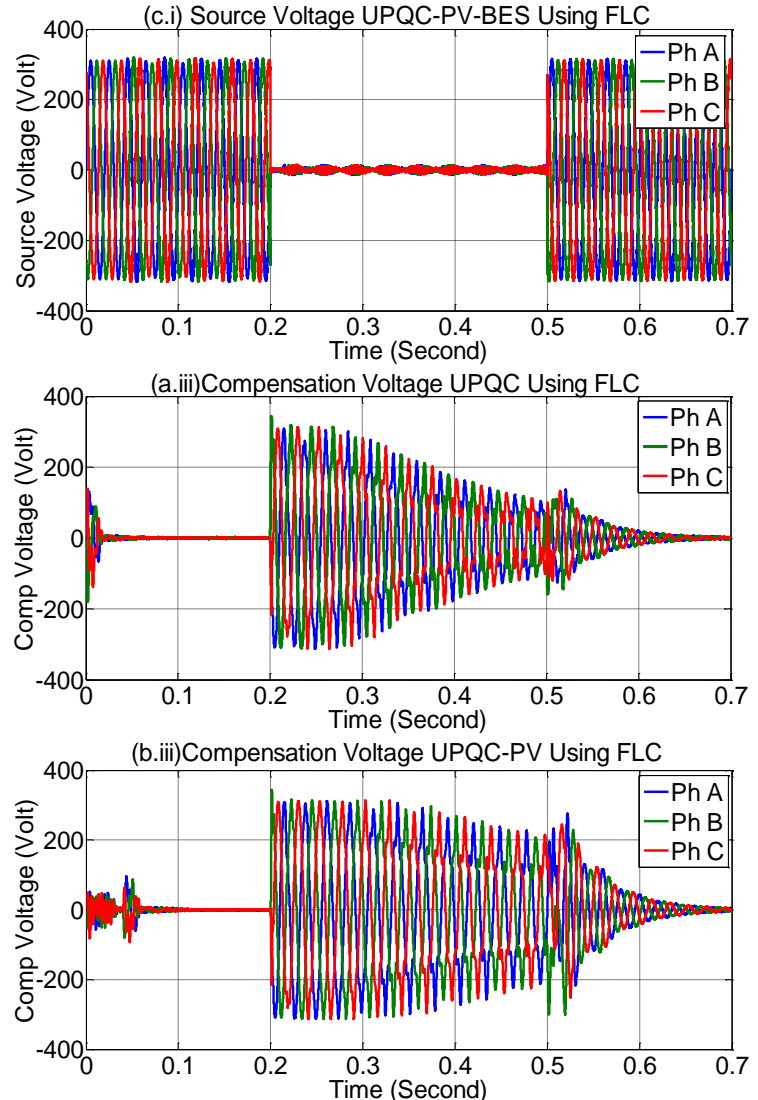

400 (c.iii)Compensation Voltage UPQC-PV-BES Using FLC
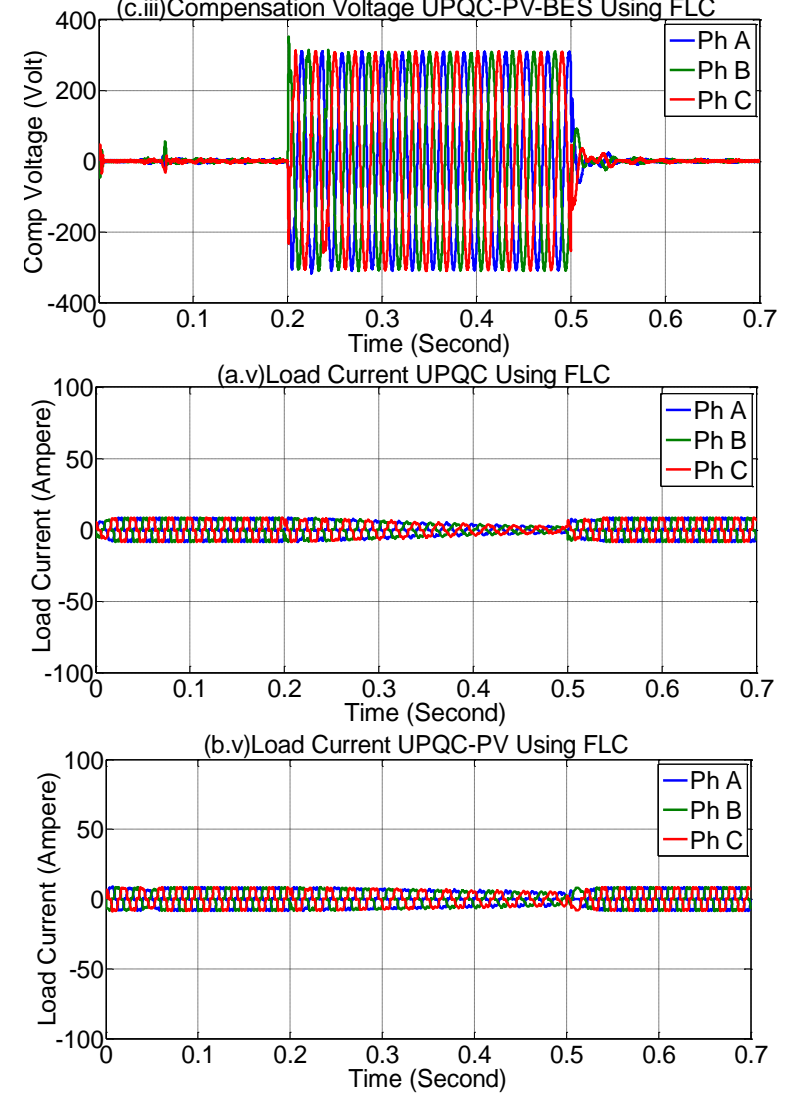
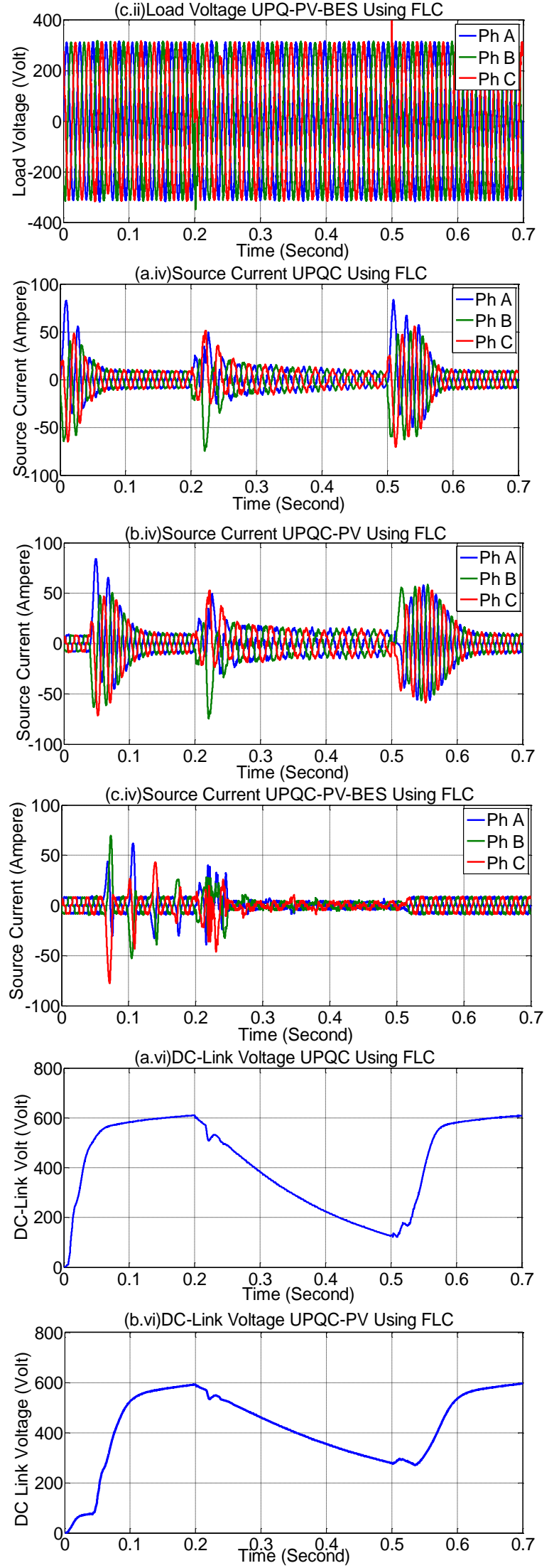
Received: January 2, 2020. Revised: February 13, 2020.
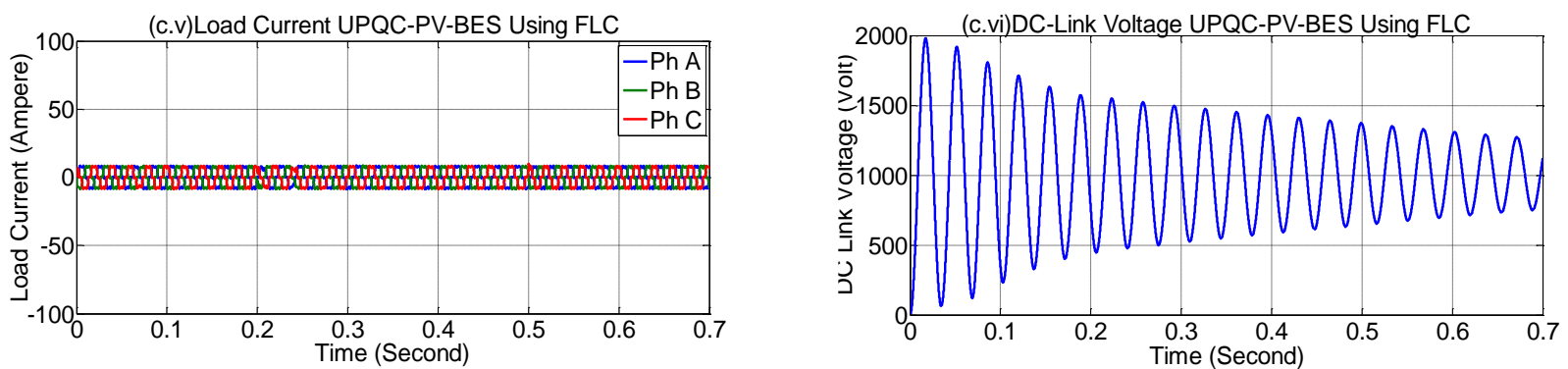

Figure. 13 Performance of UPQC combinations using FLC in Scn 6: (a) UPQC, (b) UPQC-PV, and (c) UPQC-PV-BES
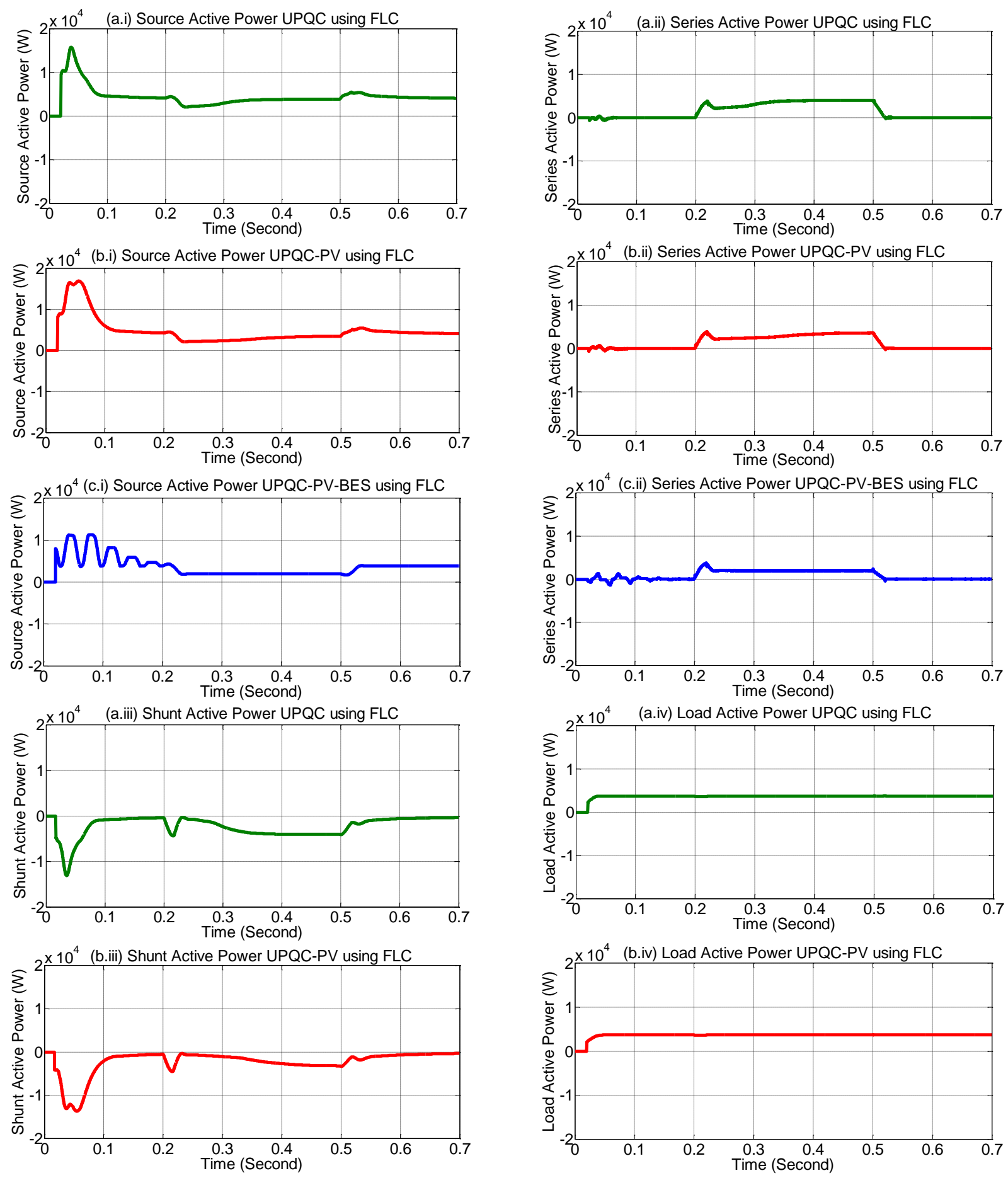

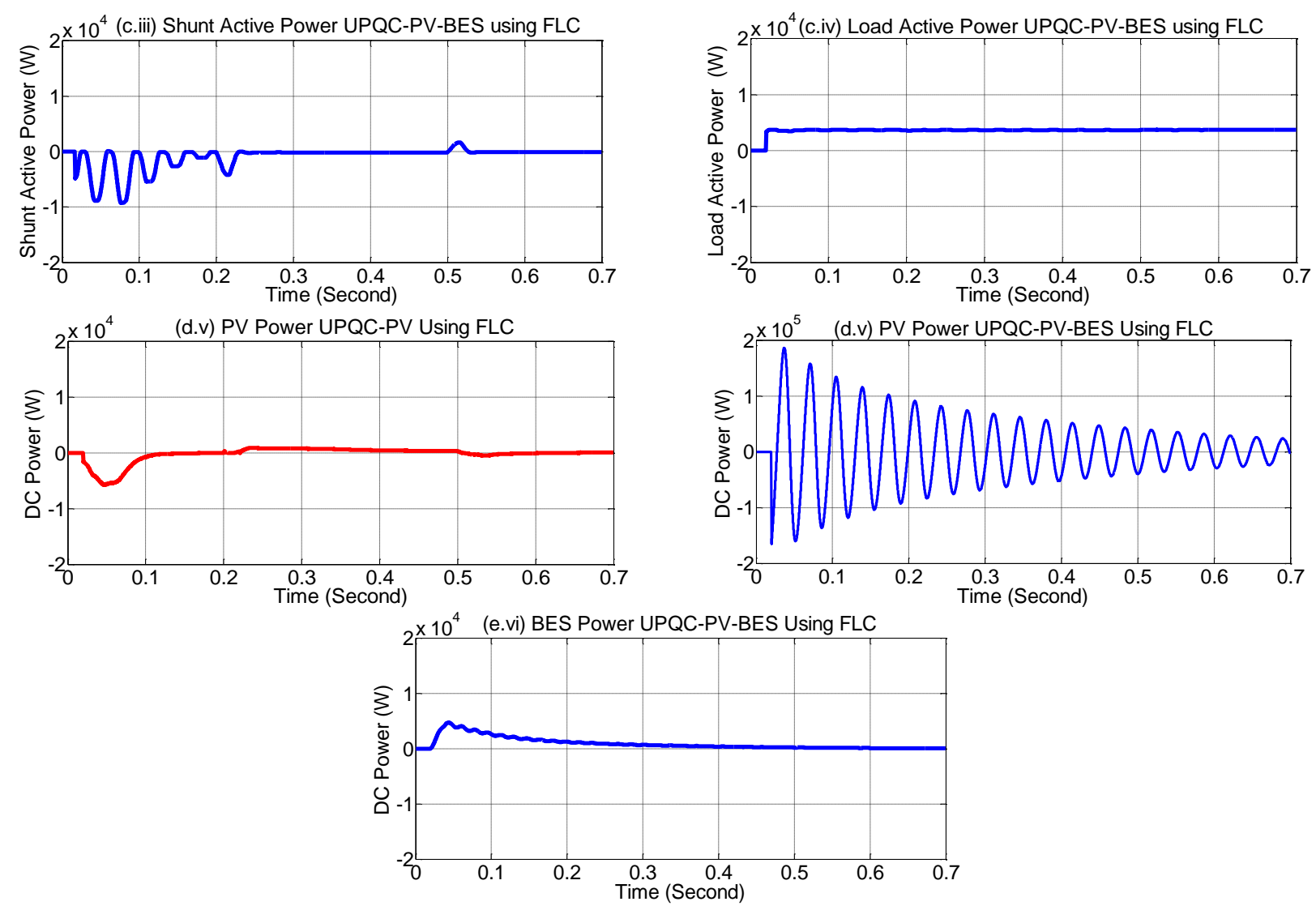

Figure. 14 Active power transfer performance on three UPQC combinations use FLC in Scn 4
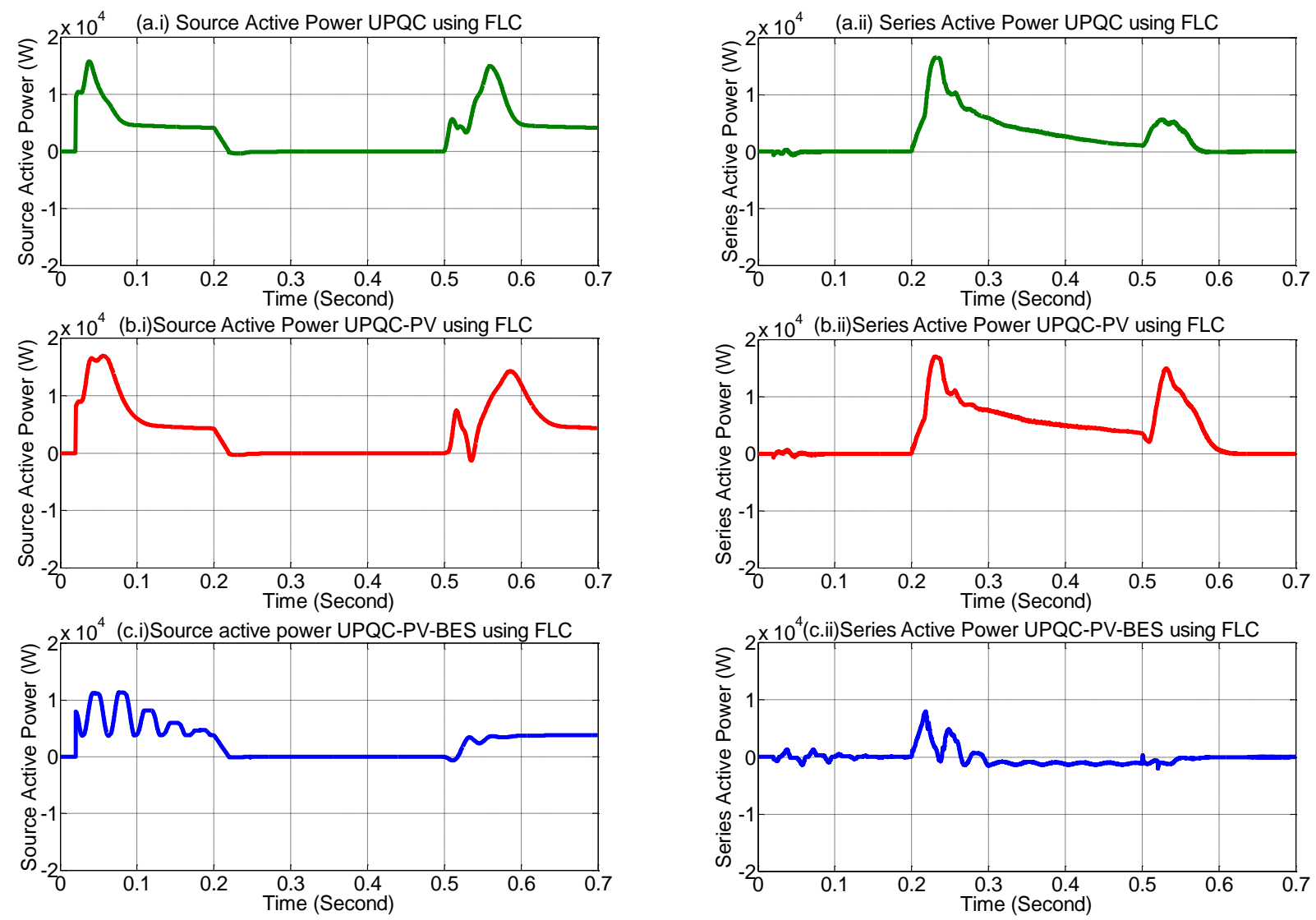

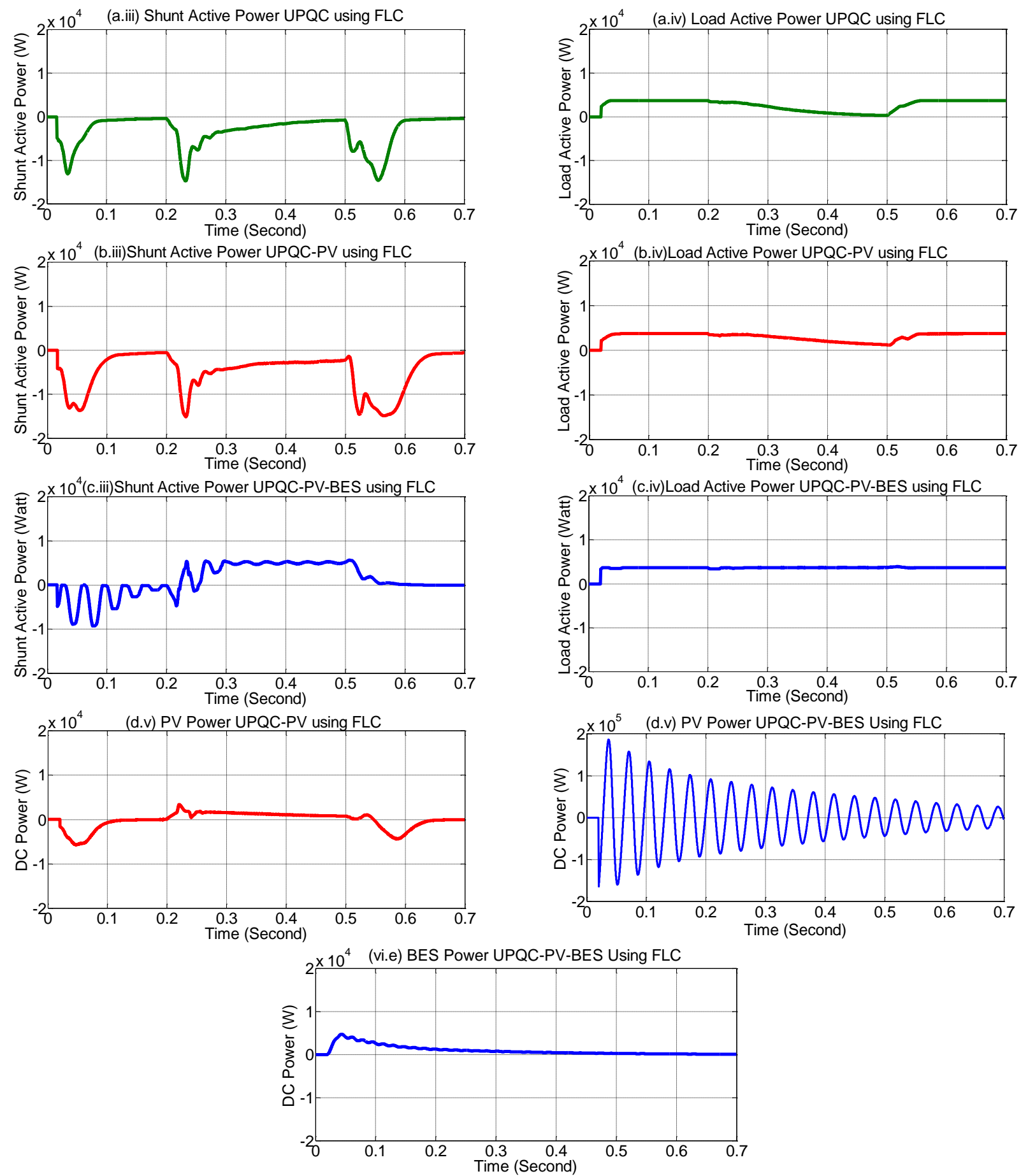

Figure. 15 Active power transfer performance on three UPQC combinations use FLC in Scn 6

Figs.14 and 15 show active power transfer performance in three UPQC combinations use FLC in Scn 4 (Sag-NL) and Scn 6 (Inter-NL). Tables 6, 7, and 8 show active power transfer in the combination of circuit: (a) UPQC, (b) UPQC-PV, and (c) UPQCPV-BES using PI and FLC in six disturbances. Table 9 shows DC power UPQC-PV and UPQCPV-BES.

Fig. 14 (a.i) shows that in Sen 4 of UPQC at $t=$ $0.2 \mathrm{~s}$ to $\mathrm{t}=0.5 \mathrm{~s}$ using FLC, the source active power $\left(P_{S}\right)$ drops to $3700 \mathrm{~W}$. The series active power $\left(P_{S e}\right)$
(Fig. 14 (a.ii)) increases by $3850 \mathrm{~W}$ and the shunt active power $\left(P_{S h}\right)$ decreases by $-3730 \mathrm{~W}$ (Fig. 14 (a.iii)), so that the load active power $\left(P_{L}\right)$ (Fig. 15 (a.iv)) becomes $3714 \mathrm{~W}$.

Fig. 14 (b.i) shows that in Scn 4 of UPQC-PV combination at $\mathrm{t}=0.2 \mathrm{~s}$ to $\mathrm{t}=0.5 \mathrm{~s}$ using FLC, the nominal of source active power $\left(P_{S}\right)$ drops to 2800 $\mathrm{W}$. The series active power $\left(P_{S e}\right)$ (Fig. 14 (b.ii)) increases by $2860 \mathrm{~W}$ and shunt active power $\left(P_{S h}\right)$ decreases by $-1840 \mathrm{~W}$ (Fig. 15 (b.iii)), PV power $\left(P_{P V}\right)$ (Fig. $14(\mathrm{~d} . \mathrm{v})$ ) increases by $650 \mathrm{~W}$, so that 
load active power $\left(P_{L}\right)$ (Fig. 14 (b.iv)) becomes of $3715 \mathrm{~W}$.

Fig. 14 (c.i) shows that in Scn 4 of UPQC-PVBES at $\mathrm{t}=0.2 \mathrm{~s}$ to $\mathrm{t}=0.5 \mathrm{~s}$ using FLC, the value of source active power $\left(P_{S}\right)$ drops to $2000 \mathrm{~W}$. The series active power $\left(P_{S e}\right)$ (Fig. 14 (c.ii)) increases by $2000 \mathrm{~W}$ and shunt power $\left(P_{S h}\right)$ decreases by $150 \mathrm{~W}$ (Fig. 14 (c.iii)), PV power $\left(P_{P V}\right)$ (Fig. 14 $\left(\right.$ d.v)) by $0 \mathrm{~W}$, and BES power $\left(P_{B E S}\right)$ (Fig. 14 (d.vi)) of $530 \mathrm{~W}$, so that load active power $\left(P_{L}\right)$ (Fig. 14 (c.iv)) equal to $3680 \mathrm{~W}$.

Fig. 15 (a.i) shows that in Sen 6 of UPQC at $t=$ $0.2 \mathrm{~s}$ to $\mathrm{t}=0.5 \mathrm{~s}$ using FLC, the source active power $\left(P_{S}\right)$ drops to $0 \mathrm{~W}$. The series active power $\left(P_{S e}\right)$ (Fig. 15 (a.ii)) increases by $3800 \mathrm{~W}$ and shunt active power $\left(P_{S e}\right)$ decreases by $-2300 \mathrm{~W}$ (Fig. 15 (a.iii)), so that load active power $\left(P_{L}\right)$ (Fig. 15 (a.iv)) decreases to $1420 \mathrm{~W}$.

Fig. 15 (b.i) shows that in Scn 6 of UPQC-PV combination at $\mathrm{t}=0.2 \mathrm{~s}$ to $\mathrm{t}=0.5 \mathrm{~s}$ using FLC, the nominal of source active power $\left(P_{S}\right)$ drops to $0 \mathrm{~W}$. The series active power $\left(P_{S e}\right)$ (Fig. 15 (b.ii)) increases by $6000 \mathrm{~W}$ and shunt active power $\left(P_{S h}\right)$ decreases by $-3100 \mathrm{~W}$ (Fig. 15 (a.iii)), PV power $\left(P_{P V}\right)$ (Fig. $\left.15(\mathrm{~d} . \mathrm{v})\right)$ rises by $1300 \mathrm{~W}$, so that load active power $\left(P_{L}\right)$ (Fig.15 (b.iv)) decreases to 2600 W.

Fig. 15 (c.i) shows that in Scn 6 of UPQC-PVBES at $\mathrm{t}=0.2 \mathrm{~s}$ to $\mathrm{t}=0.5 \mathrm{~s}$ using FLC, the value of source active power $\left(P_{S}\right)$ drops to $0 \mathrm{~W}$. The series active power $\left(P_{S e}\right)$ (Fig. 15 (c.ii)) decrease by -900 $\mathrm{W}$ and shunt active power $\left(P_{S h}\right)$ increases by 4700 $\mathrm{W}$ (Fig. 15 (c.iii)), PV power $\left(P_{P V}\right)$ (Fig. 15 (d.v)) of $0 \mathrm{~W}$, and BES power $\left(P_{B E S}\right)$ (Fig. 15 (d.vi)) of $600 \mathrm{~W}$, so that load active power $\left(P_{L}\right)$ (Fig. 15 (c.iv)) becomes $3700 \mathrm{~W}$.

Table 6. Active power transfer on UPQC

\begin{tabular}{|c|c|c|c|c|}
\hline \multirow{2}{*}{ Scn } & \multicolumn{4}{|c|}{ Active Power Transfer (Watt) } \\
\cline { 2 - 5 } & $\begin{array}{c}\text { Source } \\
\text { Power }\end{array}$ & $\begin{array}{c}\text { Series } \\
\text { Power }\end{array}$ & $\begin{array}{c}\text { Shunt } \\
\text { Power }\end{array}$ & $\begin{array}{c}\text { Load } \\
\text { Power }\end{array}$ \\
\hline \multicolumn{5}{|c|}{ PI Controller } \\
\hline 1 & 4000 & 22 & -260 & 3712 \\
\hline 2 & 4000 & 20 & -270 & 3712 \\
\hline 3 & 4080 & 32 & -280 & 3760 \\
\hline 4 & 3675 & 3820 & -3670 & 3714 \\
\hline 5 & 5760 & -1850 & 0 & 3712 \\
\hline 6 & 0 & 2850 & -1200 & 1400 \\
\hline \multicolumn{5}{|c|}{ Fuzzy Logic Controller } \\
\hline 1 & 4000 & 22 & -240 & 3714 \\
\hline 2 & 4010 & 25 & -260 & 3714 \\
\hline 3 & 4020 & 20 & -228 & 3750 \\
\hline 4 & 3700 & 3850 & -3730 & 3714 \\
\hline 5 & 5735 & -1850 & 0 & 3713 \\
\hline 6 & 0 & 3800 & -2300 & 1420 \\
\hline
\end{tabular}

Table 7. Active power transfer on UPQC-PV

\begin{tabular}{|c|c|c|c|c|}
\hline \multirow{2}{*}{ Scn } & \multicolumn{5}{|c|}{ Active Power Transfer (Watt) } \\
\cline { 2 - 5 } & $\begin{array}{c}\text { Source } \\
\text { Power }\end{array}$ & $\begin{array}{c}\text { Series } \\
\text { Power }\end{array}$ & $\begin{array}{c}\text { Shunt } \\
\text { Power }\end{array}$ & $\begin{array}{c}\text { Load } \\
\text { Power }\end{array}$ \\
\hline \multicolumn{5}{|c|}{ PI Controller } \\
\hline 1 & 4000 & 20 & -280 & 3715 \\
\hline 2 & 4000 & 20 & -290 & 3712 \\
\hline 3 & 4000 & 25 & -250 & 3750 \\
\hline 4 & 2700 & 2800 & -1800 & 3715 \\
\hline 5 & 6000 & -1700 & 0 & 3715 \\
\hline 6 & 0 & 4900 & -1900 & 2650 \\
\hline \multicolumn{5}{|c|}{ Fuzzy Logic Controller } \\
\hline 1 & 4000 & 20 & -230 & 3714 \\
\hline 2 & 4000 & 20 & -240 & 3714 \\
\hline 3 & 4000 & 25 & -250 & 3760 \\
\hline 4 & 2800 & 2860 & -1840 & 3715 \\
\hline 5 & 6000 & -1700 & 0 & 3715 \\
\hline 6 & 0 & 6000 & -3100 & 2600 \\
\hline
\end{tabular}

Table 8. Active power transfer on UPQC-PV-BES

\begin{tabular}{|c|c|c|c|c|}
\hline \multirow{2}{*}{ Scn } & \multicolumn{5}{|c|}{ Active Power Transfer (Watt) } \\
\cline { 2 - 5 } & $\begin{array}{c}\text { Source } \\
\text { Power }\end{array}$ & $\begin{array}{c}\text { Series } \\
\text { Power }\end{array}$ & $\begin{array}{c}\text { Shunt } \\
\text { Power }\end{array}$ & $\begin{array}{c}\text { Load } \\
\text { Power }\end{array}$ \\
\hline \multicolumn{5}{|c|}{ PI Controller } \\
\hline 1 & 3600 & 15 & 150 & 3690 \\
\hline 2 & 3600 & 15 & 135 & 3690 \\
\hline 3 & 3700 & 80 & 120 & 3850 \\
\hline 4 & 1700 & 1750 & 300 & 3680 \\
\hline 5 & 5500 & -1700 & 0 & 3600 \\
\hline 6 & 0 & -1100 & 5000 & 3720 \\
\hline \multicolumn{5}{|c|}{ Fuzzy Logic Controller } \\
\hline 1 & 3830 & 15 & -80 & 3690 \\
\hline 2 & 3830 & 10 & -85 & 3690 \\
\hline 3 & 3900 & 100 & -100 & 3850 \\
\hline 4 & 2000 & 2000 & -150 & 3680 \\
\hline 5 & 5725 & -1850 & 0 & 3700 \\
\hline 6 & 0 & -900 & 4700 & 3700 \\
\hline
\end{tabular}

Table 9. DC power on UPQC-PV and UPQC-PV-BES

\begin{tabular}{|c|c|c|c|}
\hline \multirow{3}{*}{ Scn } & \multicolumn{3}{|c|}{ DC Power(Watt) } \\
\cline { 2 - 4 } & PV & PV-BES \\
\cline { 2 - 4 } & PV Power & PV Power & BES Power \\
\hline \multicolumn{4}{|c|}{ PI Controller } \\
\hline 1 & 120 & 0 & 400 \\
\hline 2 & 110 & 0 & 400 \\
\hline 3 & 125 & 0 & 390 \\
\hline 4 & 650 & 0 & 410 \\
\hline 5 & -560 & 0 & 380 \\
\hline 6 & 1300 & 0 & 490 \\
\hline \multicolumn{4}{|c|}{ Fuzzy Logic Controller } \\
\hline 1 & 130 & 0 & 520 \\
\hline 2 & 125 & 0 & 520 \\
\hline 3 & 120 & 0 & 520 \\
\hline 4 & 650 & 0 & 530 \\
\hline 5 & -550 & 0 & 500 \\
\hline 6 & 1300 & 0 & 600 \\
\hline
\end{tabular}


Table 10. Efficiency of UPQC combinations

\begin{tabular}{|c|c|c|c|}
\hline \multirow{2}{*}{ Scn } & \multicolumn{3}{|c|}{ Efficiency (\%) } \\
\cline { 2 - 4 } & UPQC & UPQC-PV & UPQC-PV-BES \\
\hline \multicolumn{4}{|c|}{ PI Controller } \\
\hline 1 & 98.67 & 96.25 & 88.59 \\
\hline 2 & 98.98 & 96.67 & 88.92 \\
\hline 3 & 98.12 & 96.16 & 89.74 \\
\hline 4 & 97.09 & 85.40 & 88.46 \\
\hline 5 & 94.94 & 99.34 & 86.12 \\
\hline 6 & 84.85 & 61.63 & 84.74 \\
\hline \multicolumn{5}{|c|}{ Fuzzy Logic Controller } \\
\hline 1 & 98.20 & 94.75 & 86.12 \\
\hline 2 & 98.38 & 95.10 & 86.32 \\
\hline 3 & 98.37 & 96.54 & 87.11 \\
\hline 4 & 97.23 & 83.11 & 84.02 \\
\hline 5 & 95.57 & 99.07 & 84.57 \\
\hline 6 & 94.67 & 61.91 & 84.10 \\
\hline
\end{tabular}

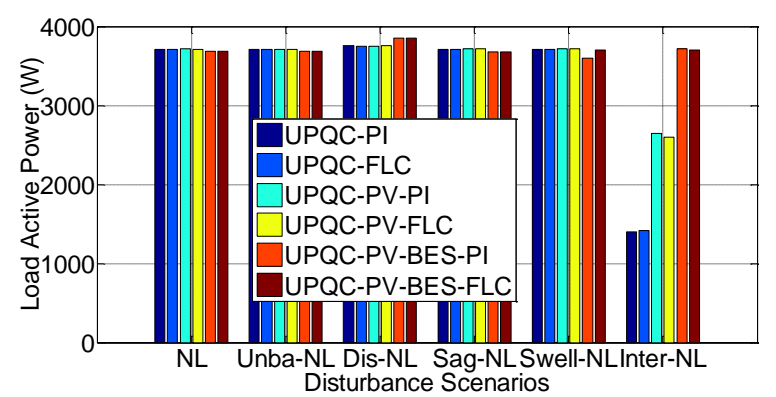

Figure. 16 Active power transfer performance on three UPQC combinations in six scns

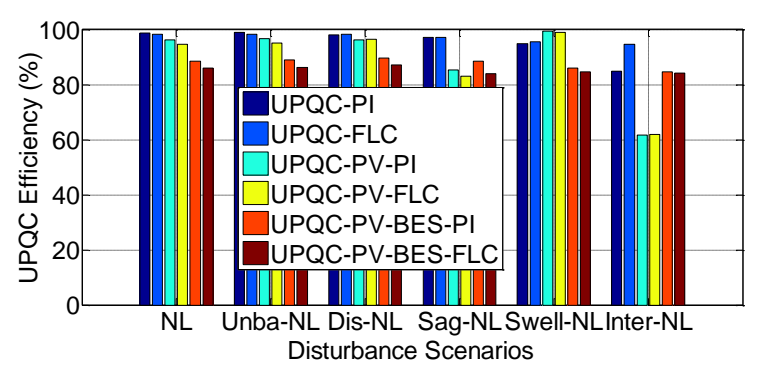

Figure. 17 Efficiency of UPQC combinations

Fig. 16 shows performance of load active power transfer in a combination of circuits: (a) UPQC, (b) UPQC-PV, and (c) UPQC-PV-BES using PI controller and FLC in six disturbance scns. The next step is to determine the efficiency of each combination i.e. (a) UPQC, (b) UPQC-PV, (c) UPQC-PV-BES using PI control and FLC. The efficiency of each circuit combination is determined using Eq. (14) and shown in Table 10 and Fig. 17. Table 10 and Fig. 17 show that in Scn 1 to 6, the combination of UPQC-PV and UPQC-PV-BES respectively, results in lower efficiency compared to using only UPQC. In Scn 4 and 6, the UPQC-PVBES combination produces higher efficiency compared than the UPQC-PV combination. In Scn 4 using FLC, UPQC-PV-BES combination produces efficiency of $84.02 \%$ compared to UPQC-PV combination of $83.11 \%$. In Scn 6 using FLC, UPQC-PV-BES model produces efficiency of $84.10 \%$ compared to UPQC-PV of $61.91 \%$.

\section{Conclusions}

The implementation of UPQC-PV-BES in 3P3W system has been presented. In disturbance scns 1 to 5 , the $3 \mathrm{P} 3 \mathrm{~W}$ system using three combinations of UPQC with PI control and FLC is still able to maintains load voltage and load current to be above $300 \mathrm{~V}$ and $8 \mathrm{~A}$. Whereas in Scn 6, only the UPQCPV-BES combination with FLC is able to maintain the load voltage and load current to be higher compared than the two UPQC combinations of $304.1 \mathrm{~V}$ and $8.421 \mathrm{~A}$ respectively. In disturbance scns 1 to 5 , the $3 \mathrm{P} 3 \mathrm{~W}$ system using three combinations of UPQC with PI controller and FLC is capable of producing load active power above $3600 \mathrm{~W}$. Whereas in Scn 6, only the combination of UPQC-PV-BES with PI controller and FLC is able to produce a load voltage of $3720 \mathrm{~W}$ and $3700 \mathrm{~W}$, respectively. In $\operatorname{Scn} 1$ to 6 , the combination of UPQC-PV-BES results in lower efficiency compared to using UPQC and UPQC-PV. In Scn 6, however, the combination of UPQC-PV-BES with FLC is able to produce higher load voltage, load current, and load active power compared to UPQCPV and UPQC. Thus, the UPQC-PV-BES model using FLC is able to compensate to the load voltage and load current, and to enhance the load active power in case an interruption voltage occurs on source bus.

This research uses BES with $100 \%$ state of charge (SoC) or fully charged. The use of BES with varying $\mathrm{SoC}(0 \%$ to $99 \%)$ is proposed as future work to find out load active power transfer performance of UPQC-PV-BES system in unfully charged BES condition.

\section{Acknowledgments}

The authors gratefully acknowledge the financial support provided by The Directorate General of Research and Development Strengthening, Directorate of Research and Community Service Ministry of Research, Technology, and Higher Education, Republic of Indonesia, through Fundamental Research accordance with the Decree Letter Number: 7/E/KPT/2019 and Contract Number: 229/SP2H/DRPM/2019 on 11 March 2019, 008/SP2H/LT/MULTI/L7/2019 on 26 March 2019, and 170/LPPM/IV/2019/UB on 4 April 2019. 


\section{Appendix}

Three phase sources: RMS voltage 380 volt (line-line), $50 \mathrm{~Hz}$, line impedance: $R_{S}=0.1 \mathrm{Ohm}$, $L_{S}=15 \mathrm{mH}$; series and shunt active filter: series inductance $L_{S e}=0.015 \mathrm{mH}$; shunt inductance $L_{S h}=$ $15 \mathrm{mH}$; injection transformers: rating $10 \mathrm{kVA}, 50$ $\mathrm{Hz}$, turn ratio $\left(\mathrm{N}_{1} / \mathrm{N}_{2}\right)=1: 1$; non-linear load: resistance $R_{L}=60 \mathrm{ohm}$, inductance $L_{L}=0.15 \mathrm{mH}$, load impedance $R_{C}=0.4 \mathrm{ohm}$ and $L_{C}=15 \mathrm{mH}$; unbalance load: resistance $R_{1}=24$ ohm, $R_{2}=12$ ohm, and $R_{3}=6 \mathrm{ohm}$, capacitance $C_{1}, C_{2}, C_{3}=2.2$ $\mu \mathrm{F}$; DC-link: voltage $V_{d c}=650$ volt and capacitance $C_{d c}=3000 \mu \mathrm{F}$; BES: type $=$ nickel metal hybrid, DC voltage $=650$ volt, rated capacity $=200 \mathrm{Ah}$, initial state of charge $=100 \%$, inductance $L_{1}=6 \mathrm{mH}$, capacitance $C_{1}=200 \mu \mathrm{F}$; solar photovoltaic: active power $=0.6 \mathrm{~kW}$ temperature $=25^{0} \mathrm{C}$, radiation $=$ $1000 \mathrm{~W} / \mathrm{m}^{2}$; PI controller: $K_{P}=0.2, K_{I}=1.5$; fuzzy logic controller model: method $=$ mamdani, composition = max-min; input MF: Vdc error $\left(V_{d c \text {-error }}\right)=$ trapmf, trimf, delta $\mathrm{Vdc}$ error $\left(\Delta V_{d c \text {-error }}\right)=$ trapmf, trimf; output $\mathrm{MF}$ : instantaneous power loss $\bar{p}_{\text {loss }}=$ trapmf, trimf.

\section{References}

[1] B. Han, B. Hae, H. Kim, and S. Back, "Combined Operation of Unified Power Quality Conditioner With Distributed Generation", IEEE Transactions on Power Delivery, Vol. 21, Issue. 1, pp. 330-338, 2006.

[2] V. Khadkikar, "Enhanching Electric Power Quality UPQC: A. Comprehensive Overview", IEEE Transactions on Power Electronics, Vol. 27, No. 5, pp. 2284-2297, 2012.

[3] S. Devassy and B. Singh, "Design and Performance Analysis of Three-Phase Solar PV Integrated UPQC", IEEE Transactions on Industry Applications, Vol. 54, Issue. 1, pp.7381, 2016.

[4] S. K. Dash and P. K. Ray, "Power Quality Improvement Utilizing PV UPQC Based on UV-PI and PR-R Controller", In: Proc. of CPSS Trans. on Power Electronics and Apps, India, Vol. 3, Issue. 3, pp. 243-253, 2018.

[5] S. K. Dash and P. K. Ray, "Investigation on The Performance of PV-UPQC Under Distorted Current and Voltage Conditions", In: Proc. of the 5th International Conference on Renewable Energy: Generation and Applications, pp. 305-309, 2018.

[6] Y. Bouzelata, E. Kurt, R. Chenni, and N. Altin, "Design and Simulation of Unified Power Quality Conditioner Fed by Solar Energy",
International Journal of Hydrogen Energy, Vol. 40, pp. 15267-15277, 2015.

[7] S. C. Ghosh and S. B. Karanki, "PV Supported Unified Power Quality Conditioner Using Space Vector Pulse Width Modulation", In: Proc. of National Power Electronics Conference College of Engineering, Pune, India, pp. 264-269, 2017.

[8] R. Senapati, R. N. Senapati, P. Behera, and M. K. Moharana, "Performance Analysis of Unified Power Quality Conditioner in a Grid connected PV System", In: Proc. of International conference on Signal Processing, Communication, Power and Embedded System, pp. 416-420, 2017.

[9] J. Jayachandran and R.M. Sachithanandam, "Performance Investigation of Unified Power Quality Conditioner Using Artificial Intelligent Controller", International Review on Modelling Simulations, Vol. 8, No. 1, pp. 48-56, 2015.

[10] K.R. Rao and K.S. Srikanth, "Improvement of Power Quality using Fuzzy Logic Controller in Grid Connected Photovoltaic Cell Using UPQC", International Journal of Power Electronics and Drive System, Vol. 5, No. 1, pp. 101-111, 2014.

[11] K.S. Srikanth, K. Mohan, and T.P. Vishnuvardhan, "Improvement of Power Quality for Microgrid Using Fuzzy Based UPQC Controller", In: Proc. of International Conference on Electrical, Electronics, Signals, Communication and Optimization, pp. 1-6, 2015.

[12] A. Amirullah, O. Penangsang, and A. Soeprijanto, "High Performance of Unified Power Quality Conditioner and Battery Energy Storage Supplied by Photovoltaic Using Artificial Intelligent Controller', International Review on Modelling and Simulations, Vol. 11, No. 4, pp. 221-234, 2018.

[13] V.P. Pires, D. Foito, A. Cordiero, and J.F. Martins, "PV Generators Combined With UPQC Based on a Dual Converter Structure", In: Proc. of IEEE 26th International Symposium on Industrial Electronics, pp.17811786, 2017.

[14] L.B.G. Campanhol, S.A.O. da Silva, and A.A.O. Junior, "A Three-Phase Four-Wire GridConnected Photovoltaic System Using a Dual Unified Power Quality Conditioner", In: Proc. of IEEE 13th Brazilian Power Electronics Conference and 1st Southern Power Electronics Conference, 2015.

[15] S. Paramanik, K. Sarker, D. Chatterjee, and S.K Goswami, "Smart Grid Power Quality 
Improvement Using Modified UPQC", In: Proc. of Devices for Integrated Circuit, pp.356360, 2019.

[16] A.R. Reisi, M.H. Moradi, and H. Showkati, "Combined Photovoltaic and Unified Power Quality Controller to Improve Power Quality", Solar Energy, Vol. 88, pp.154-162, 2013.

[17] S. Y. Kamble and M. M. Waware, "Unified Power Quality Conditioner for Power Quality Improvement", In: Proc. of International Multi Conference on Automation, Computing, Communication, Control and Compressed Sensing, pp. 432-437, 2013.

[18] M. Hembram and A. K. Tudu, "Mitigation of Power Quality Problems Using Unified Power Quality Conditioner (UPQC)", In: Proc. of International Conference on Computer, Communication, Control and Information Technology, pp.1-5, 2015.

[19] Y. Pal, A. Swarup, and B. Singh, "A Comparative Analysis of Different Magnetic Support Three Phase Four Wire Unified Power Quality Conditioners-A Simulation Study", Electrical Power and Energy System, Vol. 47, pp. 437-447, 2013.

[20] A. Amirullah and A. Kiswantono, "Power Quality Enhancement of Integration Photovoltaic Generator to Grid under Variable Solar Radiation Level using MPPT-Fuzzy", International Journal of Electrical and Computer Engineering, Vol. 6, No. 6, pp.26292642, 2016.

[21] M. Ucar and S. Ozdemir, "3-Phase 4-Leg Unified Series-Parallel Active Filter System with Ultracapacitor Energy Storage for Unbalanced Voltage Sag Mitigation", Electrical Power and Energy Systems, Vol. 49, pp. 149-159, 2013. 